\title{
Characterization of Pt-Pd/C Electrocatalyst for Methanol Oxidation in Alkaline Medium
}

\author{
S. S. Mahapatra ${ }^{1}$ and J. Datta ${ }^{2}$ \\ ${ }^{1}$ Department of Chemical and Polymer Engineering, Birla Institute of Technology, Mesra, Jharkhand, Ranchi 835 215, India \\ ${ }^{2}$ Department of Chemistry, Bengal Engineering and Science University, Shibpur, West Bengal, Howrah 711 103, India
}

Correspondence should be addressed to S. S. Mahapatra, ssmahapatra@bitmesra.ac.in

Received 14 March 2011; Accepted 4 July 2011

Academic Editor: Pei Kang Shen

Copyright (C) 2011 S. S. Mahapatra and J. Datta. This is an open access article distributed under the Creative Commons Attribution License, which permits unrestricted use, distribution, and reproduction in any medium, provided the original work is properly cited.

The Pt-Pd/C electrocatalyst was synthesized on graphite substrate by the electrochemical codeposition technique. The physicochemical characterization of the catalyst was done by SEM, XRD, and EDX. The electrochemical characterization of the Pt-Pd/C catalyst for methanol electro-oxidation was studied over a range of $\mathrm{NaOH}$ and methanol concentrations using cyclic voltammetry, quasisteady-state polarization, chronoamperometry, and electrochemical impedance spectroscopy. The activity of methanol oxidation increased with $\mathrm{pH}$ due to better $\mathrm{OH}$ species coverage on the electrode surface. At methanol concentration $(>1.0 \mathrm{M})$, there is no change in the oxidation peak current density because of excess methanol at the electrode surface and/or depletion of $\mathrm{OH}^{-}$at the electrode surface. The Pt-Pd/C catalyst shows good stability and the low value of Tafel slope and charge transfer resistance. The enhanced electrocatalytic activity of the electrodes is ascribed to the synergistic effect of higher electrochemical surface area, preferred $\mathrm{OH}^{-}$adsorption, and ad-atom contribution on the alloyed surface.

\section{Introduction}

The direct alcohol fuel cell (DAFC) has now emerged as one of the prospective power sources, since liquid alcohol fuels have several merits over gaseous fuel such as high energy density and, availability of gasoline infrastructure, and these can be used directly without the necessity of reforming. Among the different fuel candidates, methanol has been considered as one of the most appropriate fuel for the DAFCs because of its low molecular weight, simplest structure, and very high energy density $\left(6.1 \mathrm{kWh} \mathrm{kg}^{-1}\right)$. Methanol can be generated from a number of different sources like natural gas, oil, coal, or biomass, since direct methanol fuel cell (DMFC) can operate by feeding methanol directly to the reactor without using a reformer and the system is compact and suitable for portable and mobile power generation $[1,2]$. However, it is difficult to carry out the complete oxidation of methanol in acid with $\mathrm{Pt}$ alone as the electrocatalyst. The electro-oxidation of methanol in acid media has been studied extensively, and several parallel reactions are reported to limit the electropotentiality of methanol in acid media $[3,4]$. Formaldehyde, formic acid and $\mathrm{CO}$ are considered as reaction intermediates in acidic media. The formation of surface adsorbed intermediate species could act as poison for subsequent methanol adsorption and oxidation. The CO is strongly adsorbed and linearly bonded, which leads to self-poisoning of Pt electrocatalyst. Further, adsorption of methanol on poisoned Pt cannot occur, and methanol oxidation drops to a minimum rate [5-7]. Another problem associated with DMFC in acid media is the methanol crossover from anode through the polymeric electrolyte membrane (PEM) poisoning cathode, which results in depolarizing reaction on the cathode and considerable potential loss even under open-circuit conditions [8]. The rate of methanol permeation is particularly high due to electro-osmotic drag associated with the proton conduction mechanism.

Platinum, mostly used as an electrocatalyst, has a low activity for methanol oxidation in acid solution due to its inability to adsorb suitable oxygen-containing species in potential region of methanol adsorption. To overcome this problem, a second and some time a third metal have been advocated as cocatalyst. Transition metal that display one or several redox couples containing hydrous species at potential close to that of hydrogen or methanol oxidation are mainly 


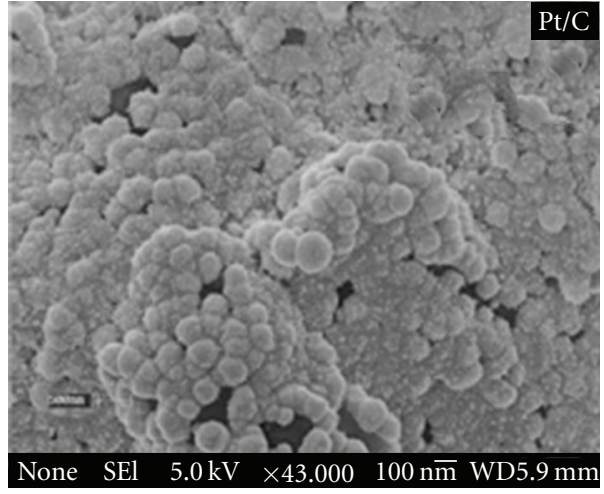

(a)

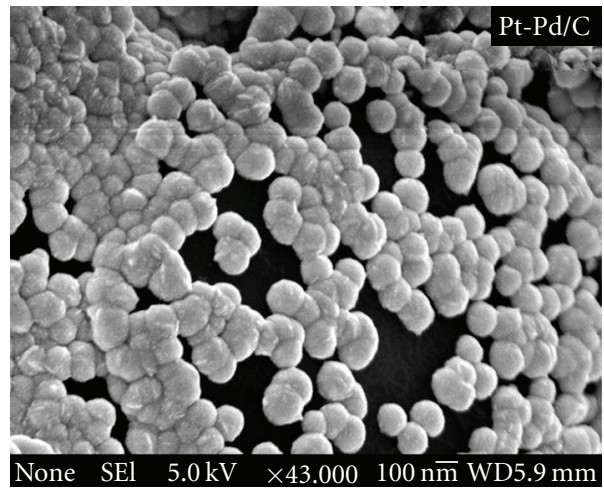

(b)

FIgure 1: Scanning electron micrographs (SEM) of Pt/C and Pt-Pd/C electrocatalysts.

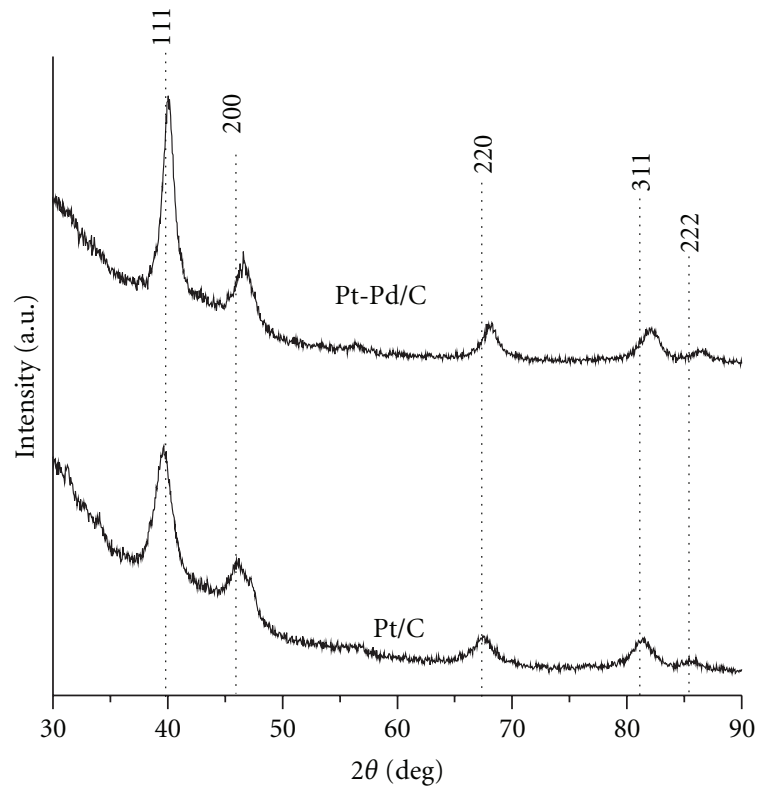

Figure 2: X-ray diffraction (XRD) pattern of $\mathrm{Pt} / \mathrm{C}$ and $\mathrm{Pt}-\mathrm{Pd} / \mathrm{C}$ electrocatalysts.

utilized for the purpose $[9,10]$. Superior catalytic activities have been reported for methanol oxidation on Pt-based alloys in acidic media, such as Pt-Ru, Pt-Sn, Pt-Os, Pt-Ru-Os, and Pt-Ru-Ir [11-16]. Although incorporation of second and third metal enhances the catalytic activity to some extent, further improvement of the reaction kinetics of anode is essential to make it suitable for commercial viability of DMFCs. To date, although, the majority of the work related to DMFC has been conducted in acidic media, few studies of methanol oxidation in alkaline solutions have been reported [4, 17-22]. These studies have demonstrated higher activity for methanol oxidation as compared to that in acid media. Interest in the alkaline methanol fuel cell has arisen because of its better oxygen reduction kinetics in alkaline condition than in acidic environment, simplicity, low cost, and comparable efficiency compared to other types of fuel cells [23]. Beside these, alkaline fuel cell provides

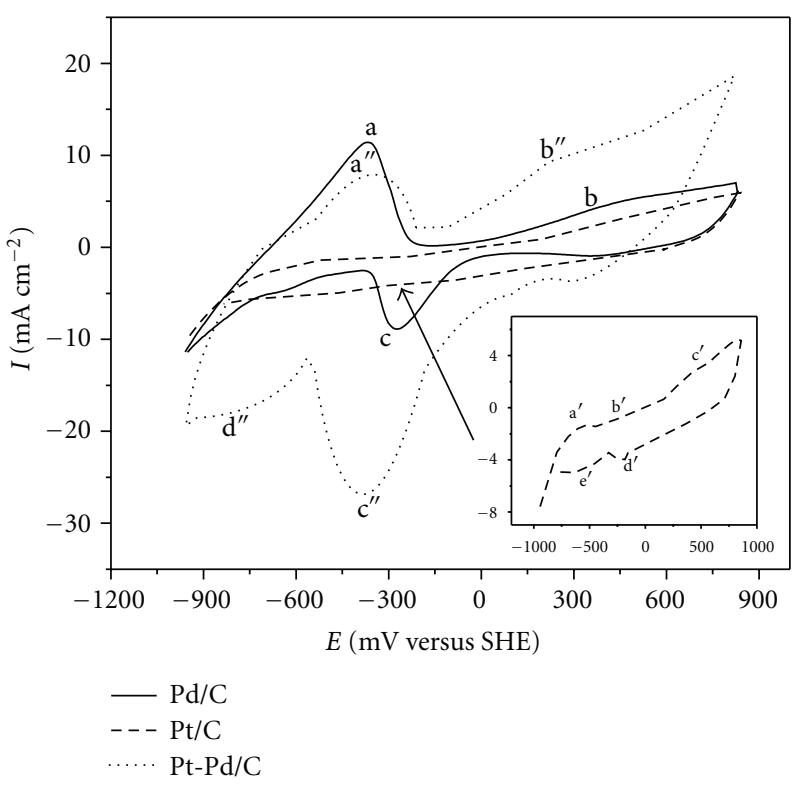

Figure 3: Cyclic voltammograms of $\mathrm{Pd} / \mathrm{C}, \mathrm{Pt} / \mathrm{C}$ and $\mathrm{Pt}-\mathrm{Pd} / \mathrm{C}$ electrodes in $0.5 \mathrm{M} \mathrm{NaOH}$ at $25^{\circ} \mathrm{C}$ and sweep rate of $50 \mathrm{mV} \mathrm{s}^{-1}$.

benefits like higher efficiency and wider selection of possible electrocatalysts. The generation of $\mathrm{H}^{+}$ions in the anodic reaction is an obvious reason for the favored kinetics in alkaline solution. The electrocatalysts used in the alkaline fuel cell are Pt, Ni [24, 25], $\mathrm{Fe}(\mathrm{III})$ [26], $\mathrm{Al}[26]$, and Pt-Ru [27]. The application of alkaline electrolytes to the DMFC could lead to a reduction in catalyst loading and allow the use of less expensive nonprecious metal catalysts. Despite the fact that the efficiency of DMFCs can be improved by well-balanced coadsorption of methanol and $\mathrm{OH}^{-}$anions at low potential in alkaline solution, the effective use of alkali media has come to realization only in the last few years. Consequently, the kinetics and mechanistic study of methanol oxidation in alkaline solution at different Ptbased catalysts may provide valuable information for the development of new and powerful catalysts. 


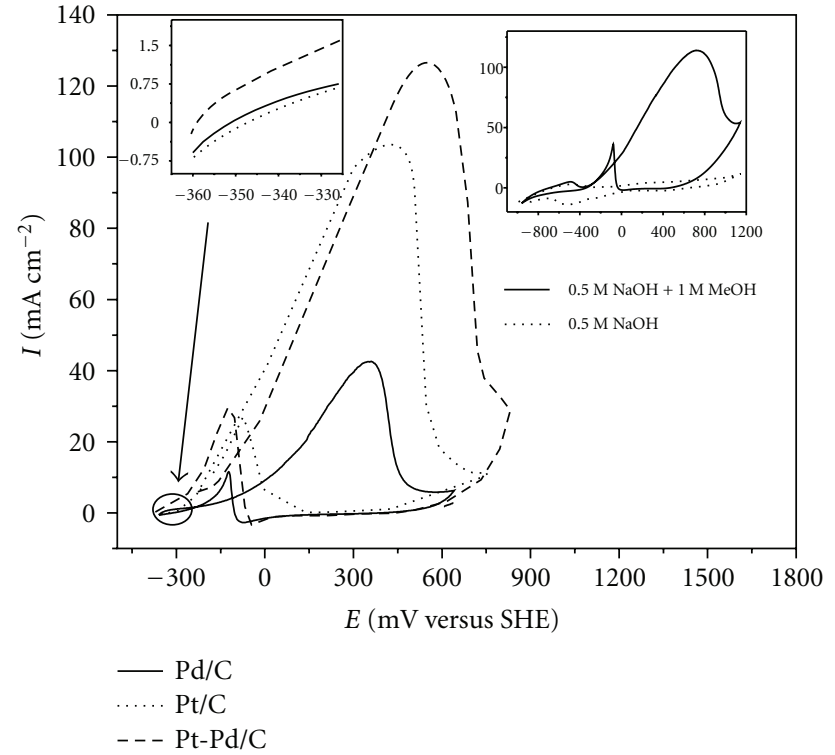

Figure 4: Cyclic voltammograms for methanol oxidation on $\mathrm{Pd} / \mathrm{C}$, $\mathrm{Pt} / \mathrm{C}$, and $\mathrm{Pt}-\mathrm{Pd} / \mathrm{C}$ electrodes in a mixture of $0.5 \mathrm{M} \mathrm{NaOH}$ and $1.0 \mathrm{M}$ methanol at $25^{\circ} \mathrm{C}$ and sweep rate of $50 \mathrm{mV} \mathrm{s}^{-1}$; inset: cyclic voltammograms of $\mathrm{Pt}-\mathrm{Pd} / \mathrm{C}$ electrode in $0.5 \mathrm{M} \mathrm{NaOH}$ with and without $1.0 \mathrm{M}$ methanol at identical conditions.

The overall oxidation reaction equation for the methanol in alkaline medium is supposed to be

$$
\mathrm{CH}_{3} \mathrm{OH}+6 \mathrm{OH}^{-} \longrightarrow \mathrm{CO}_{2}+5 \mathrm{H}_{2} \mathrm{O}+6 \mathrm{e}^{-} \text {. }
$$

Complex process of methanol electro-oxidation involving 6-electron transfer and several intermediate organic species are produced. Methanol oxidation in alkaline medium proceeds through following paths:

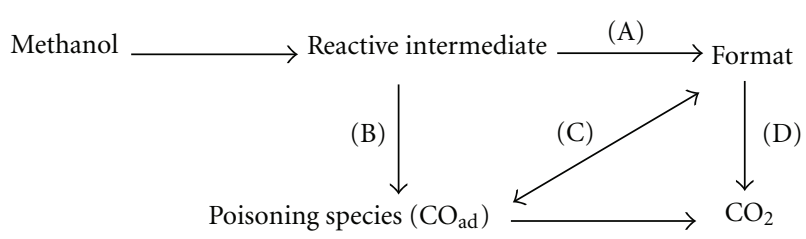

Formate and $\mathrm{CO}_{2}$ (as carbonate) are the main soluble reaction products, and $\mathrm{CO}$ has been detected as the main poisoning species in alkaline medium [28-30]. The (CO) ads species formation follows pathway (B) or (C) and is responsible for current decay during methanol oxidation. The selectivity of product formation largely depends on the potential as well as temperature. The first step of the oxidation process is the dissociative adsorption of methanol followed by subsequent dehydrogenation, water activation, noble metal oxide formation at higher potentials, its reduction, and finally desorption or oxidation of the organic species by reactivation.

Hydroxide ions get adsorbed on the electrode surface and initiate the formation of surface hydroxide and oxide species.
The associated electrochemical reaction occurring at the electrode-electrolyte interface is as follows [22, 27]:

$$
\begin{gathered}
\mathrm{M}+\mathrm{OH}^{-} \rightleftharpoons \mathrm{Pt}-(\mathrm{OH})_{\mathrm{ads}}+\mathrm{e}^{-}, \\
\mathrm{M}+6 \mathrm{OH}^{-} \rightleftharpoons[\mathrm{M}(\mathrm{OH}) 6]_{\mathrm{sol}}^{2-}+4 \mathrm{e}^{-}, \\
\mathrm{M}-\mathrm{OH}+\mathrm{M}-\mathrm{H} \longrightarrow \mathrm{M}-\mathrm{O}+\mathrm{H}_{2} \mathrm{O} .
\end{gathered}
$$

A low level of hydrous oxide may be formed at the metal sites and surface defects due to the repetitive formation and reduction of thin compact layer via the above reactions. This hydrous oxide supplies the active oxygen atom to oxidize the organic species. The $\mathrm{OH}^{-}$ions required for the equilibrium are mainly supplied by the solution $\mathrm{OH}^{-}$ion at higher potential. Pd incorporation into the Pt matrix, the hydrogen adsorption, and desorption characteristics is significantly improved at much lower potential than that on the Pt alone. The hydrogen desorption particularly at the Pd sites plays important role in the anodic potential region in alkali medium and activates the catalyst surface for deprotonation. The surface hydroxides are more readily formed in the presence of $\mathrm{Pd}$ in the catalyst matrix. Thus, the poisoning effect of $\mathrm{CO}_{\mathrm{ad}}$ is efficiently reduced due to the synergic effect of $\mathrm{Pt}$ and $\mathrm{Pd}$ in the matrix.

Dissociative chemisorption of methanol molecules on anode surface proceeds through the following steps:

$$
\begin{gathered}
\mathrm{M}+\left(\mathrm{CH}_{3} \mathrm{OH}\right)_{\mathrm{sol}} \rightleftharpoons \mathrm{M}-\left(\mathrm{CH}_{3} \mathrm{OH}\right)_{\mathrm{ads}} \\
\mathrm{M}-\left(\mathrm{CH}_{3} \mathrm{OH}\right)_{\mathrm{ads}}+\mathrm{OH}^{-} \longrightarrow \mathrm{M}-\left(\mathrm{CH}_{3} \mathrm{O}\right)_{\mathrm{ads}}+\mathrm{H}_{2} \mathrm{O}+\mathrm{e}^{-}, \\
\mathrm{M}-\left(\mathrm{CH}_{3} \mathrm{O}\right)_{\mathrm{ads}}+\mathrm{OH}^{-} \longrightarrow \mathrm{M}-\left(\mathrm{CH}_{2} \mathrm{O}\right)_{\mathrm{ads}}+\mathrm{H}_{2} \mathrm{O}+\mathrm{e}^{-}, \\
\mathrm{M}-\left(\mathrm{CH}_{2} \mathrm{O}\right)_{\mathrm{ads}}+\mathrm{OH}^{-} \longrightarrow \mathrm{M}-(\mathrm{CHO})_{\mathrm{ads}}+\mathrm{H}_{2} \mathrm{O}+\mathrm{e}^{-} \\
\mathrm{M}-(\mathrm{CHO})_{\mathrm{ads}}+\mathrm{OH}^{-} \longrightarrow \mathrm{M}-(\mathrm{CO})_{\mathrm{ads}}+\mathrm{H}_{2} \mathrm{O}+\mathrm{e}^{-} \\
\mathrm{M}-(\mathrm{CO})_{\mathrm{ads}}+\mathrm{OH}^{-} \longrightarrow \mathrm{M}-(\mathrm{COOH})_{\mathrm{ads}}+\mathrm{e}^{-} \\
\mathrm{M}-(\mathrm{COOH})_{\mathrm{ads}}+\mathrm{OH}^{-} \longrightarrow \mathrm{M}+\mathrm{CO}_{2}+\mathrm{H}_{2} \mathrm{O}+\mathrm{e}^{-}
\end{gathered}
$$

where M stands for Pt-Pd.

In the presence of adequate alkali, the oxidation of $\mathrm{M}-(\mathrm{CHO})_{\mathrm{ads}}$ and $\mathrm{M}-(\mathrm{CO})_{\text {ads }}$ may proceed directly through the steps (12) and (13) to the ultimate production of $\mathrm{CO}_{2}$

$$
\begin{aligned}
& \mathrm{M}-(\mathrm{CHO})_{\mathrm{ads}}+3 \mathrm{OH}^{-} \longrightarrow \mathrm{M}+\mathrm{CO}_{2}+2 \mathrm{H}_{2} \mathrm{O}+3 \mathrm{e}^{-}, \\
& \mathrm{M}-(\mathrm{CO})_{\mathrm{ads}}+2 \mathrm{OH}^{-}(\text {on } \mathrm{M}) \longrightarrow \mathrm{M}+\mathrm{CO}_{2}+\mathrm{H}_{2} \mathrm{O}+2 \mathrm{e}^{-} .
\end{aligned}
$$

The strength of the bonding of $(\mathrm{CHO})_{\mathrm{ads}}$ on the surface probably determines the entire rate of the reaction. In general, the chemisorbed bonding of $(\mathrm{CHO})_{\text {ad }}$ on Pt group of metals in alkali is weak such that further oxidation takes place without much difficulty, that is, without irreversibly blocking the electrode's active sites. The several intermediate organic species have been identified by FTIR spectroscopic study which revealed that the $\mathrm{CO}$ species are found to be linearly bonded to $\mathrm{Pt}$ sites $(\mathrm{Pt}-\mathrm{C}=\mathrm{O})$ and bridge bonded to $\mathrm{Pd}$ sites 
$\left(\mathrm{Pd}_{2} \mathrm{C}=\mathrm{O}\right)$ [27]. Complete removal of $\mathrm{CO}$ species may not be possible at low potential, as they strongly bind to the electrode surface. However, at higher potential, highly active oxygen atoms again become available and the poisonous $\mathrm{PtCO}$ or $\mathrm{Pd}_{2} \mathrm{CO}$ species are oxidized via the reaction (10) or (13).

The reduction of oxygen takes place at cathode and proceeds through following steps:

$$
\begin{aligned}
& \frac{3}{2} \mathrm{O}_{2}+3 \mathrm{H}_{2} \mathrm{O}+6 \mathrm{e}^{-} \longrightarrow 6 \mathrm{OH}^{-} \\
& \mathrm{CO}_{2}+2 \mathrm{OH}^{-} \longrightarrow \mathrm{CO}_{3}^{2-}+\mathrm{H}_{2} \mathrm{O}
\end{aligned}
$$

Therefore, the overall reaction is as follows:

$$
\mathrm{CH}_{3} \mathrm{OH}+8 \mathrm{OH}^{-} \longrightarrow \mathrm{CO}_{3}^{2-}+6 \mathrm{H}_{2} \mathrm{O}+6 \mathrm{e}^{-} \text {. }
$$

The disadvantage of alkaline solution is its progressive carbonation with $\mathrm{CO}_{2}$ (15), whereby carbonate and bicarbonate are produced, which lower the concentration of the electrolytes affecting the cell performance [26, 31]. The performance of the AFC can be improved by the electrolyte recirculation, and continuous $\mathrm{CO}_{2}$ removal may prevent significant carbonation [27] with the development of a membrane-free laminar flow fuel cell (LFFC) and alkalineanion exchange membrane (AAEM) for application in AFC which have shown improved performance and very little methanol permeability from anode to cathode chamber [3234].

In fuel cells, the high loading of expensive Pt on carbon has severely limited their use making DAFCs still prohibitive from broad commercialization. One of the ways for cutting down the Pt consumption in DAFCs is to reduce the metal loading. Other ways deal with the development of an anode catalyst which is cheaper, efficient, and more abundant than Pt [35]. In this context, our aim is to reduce the Pt loading without compromising the efficiency of the catalyst, and Pd is of our interest, because it is less costly and at least 50 times more abundant in the earth than Pt [36]. It has been used as an excellent electrocatalyst for oxidizing small organic molecules including methanol [37]. Pd has the power to reduce protons, store, and release hydrogen and is further used to remove adsorbed $\mathrm{CO}$ formed from the methanol electro-oxidation, thus abating the poisoning effect $[38,39]$. It has been reported that the presence of $\mathrm{Pd}$ assists the oxidation of $\mathrm{C}_{1}$ alcohol to $\mathrm{CO}_{2}$ by reaction of $\mathrm{CO}$ with hydrogen occluded in the $\mathrm{Pd}$ lattice at significantly more negative potential [39]. The release of hydrogen by $\mathrm{Pd}$ may thus provide a viable route for lowering the surface concentration of adsorbed $\mathrm{CO}$, permitting the continual oxidation of organic molecules at the Pd surface. Pd is just above Pt in the same group of the periodic table. Therefore, they share some common features and can be coupled with each other. Moreover, Pd can form stronger bonds with other metals other than itself [40]. Therefore, a combination of $\mathrm{Pt}$ and $\mathrm{Pd}$ that changes the electronic character in thin coating of catalysts layer deposit may be helpful in reducing poisoning by oxidizing $\mathrm{CO}$ to $\mathrm{CO}_{2}$. It is also reported that electrooxidation of methanol on Pd-modified Pt proceeds through the "direct pathway", and the suppression of CO formation on Pd-modified Pt was observed [41]. The atomic radius of $\mathrm{Pt}$ is similar to that of $\mathrm{Pd}(0.138$ and $0.137 \mathrm{~nm}$, resp. $)$ so that the substitution of Pt with Pd atoms expands the lattice only slightly and Pt-Pd alloy is found to bear the f.c.c. structure. Despite possessing interesting electrocatalytic properties, $\mathrm{Pd}$ has been less extensively studied for fuel cell applications compared to Pt.

The work in this paper entails a comprehensive study on the physicochemical as well as electrochemical characterization of the synthesized Pt-Pd/C electrode towards oxidation of methanol in $\mathrm{NaOH}$ media. For physicochemical characterization, different techniques like scanning electron microscopy (SEM), energy dispersive X-ray spectroscopy (EDX), and X-ray diffraction (XRD) study were employed. Electrochemical techniques like voltammetry, chronoamperometry, and electrochemical impedance spectroscopy (EIS) were used to derive the electrocatalytic behavior of the electrodes towards methanol oxidation.

\section{Experimental}

2.1. Materials. Methanol $(\mathrm{MeOH})$ was purified by using standard procedure [42] and stored over a Type 3A molecular sieve beads. The other reagents such as $\mathrm{NaOH}$ and $\mathrm{HCl}$ used in this work were of GR grade purity (Merck) and $\mathrm{H}_{2} \mathrm{PtCl}_{6}$. $6 \mathrm{H}_{2} \mathrm{O}$ and $\mathrm{PdCl}_{2}$ were obtained from Arora Matthey Ltd. The graphite block (saw cut finish grade) used as the catalyst substrate was procured from Graphite India Limited. All the solutions were freshly prepared with Milli-Q water.

\subsection{Preparation of $\mathrm{Pt} / \mathrm{C}, \mathrm{Pd} / \mathrm{C}$, and $\mathrm{Pt}-\mathrm{Pd} / \mathrm{C}$ Electrocatalysts.} Electrochemical deposition of $\mathrm{Pt}$ and $\mathrm{Pd}$ or codeposition of $\mathrm{Pt}$ and $\mathrm{Pd}$ were made on coupons of graphite samples with surface area of $0.65 \mathrm{~cm}^{2}$. Electrodeposition of $\mathrm{Pt}$ and $\mathrm{Pd}$ were carried out using $0.05 \mathrm{M} \mathrm{H}_{2} \mathrm{PtCl}_{6} \cdot 6 \mathrm{H}_{2} \mathrm{O}$ and $0.05 \mathrm{M} \mathrm{PdCl}_{2}$ solutions, respectively. Both $\mathrm{H}_{2} \mathrm{PtCl}_{6} \cdot 6 \mathrm{H}_{2} \mathrm{O}$ and $\mathrm{PdCl}_{2}$ solutions were prepared in $2.0 \mathrm{MHCl}$ and Milli-Q water. For electrochemical codeposition of $\mathrm{Pt}$ and $\mathrm{Pd}$, an equimolar mixture of $0.05 \mathrm{M} \mathrm{H}_{2} \mathrm{PtCl}_{6} \cdot 6 \mathrm{H}_{2} \mathrm{O}$ and $0.05 \mathrm{M} \mathrm{PdCl}_{2}$ was used. For each case, electrodeposition was performed at room temperature under galvanostatic control by applying $5 \mathrm{~mA} \mathrm{~cm}^{-2}$ current with the help of computer controlled PG Stat (AUTOLAB 30) for 10 minutes duration. Catalyst loading for each electrode was maintained at $0.5 \mathrm{mg} \mathrm{cm}^{-2}$.

\subsection{Physicochemical Characterization of the Electrocatalysts.} Bulk composition of the Pt-Pd/C electrocatalyst was determined by energy dispersive X-ray spectroscopy (EDX), while scanning electron microscopy (SEM) was employed to reveal the surface morphology. All these measurements were done with a JSM-6700F FESEM at an accelerating potential of $5 \mathrm{kV}$. In order to obtain information about the surface and bulk structure of the catalyst, X-ray diffraction (XRD) study was carried out with the help of Philips PW 1140 parallel beam X-ray diffractometer with Bragg-Bretano focusing geometry and monochromatic $\mathrm{Cu} \mathrm{K}_{\alpha}$ radiation $(\lambda=1.54 \AA)$. 


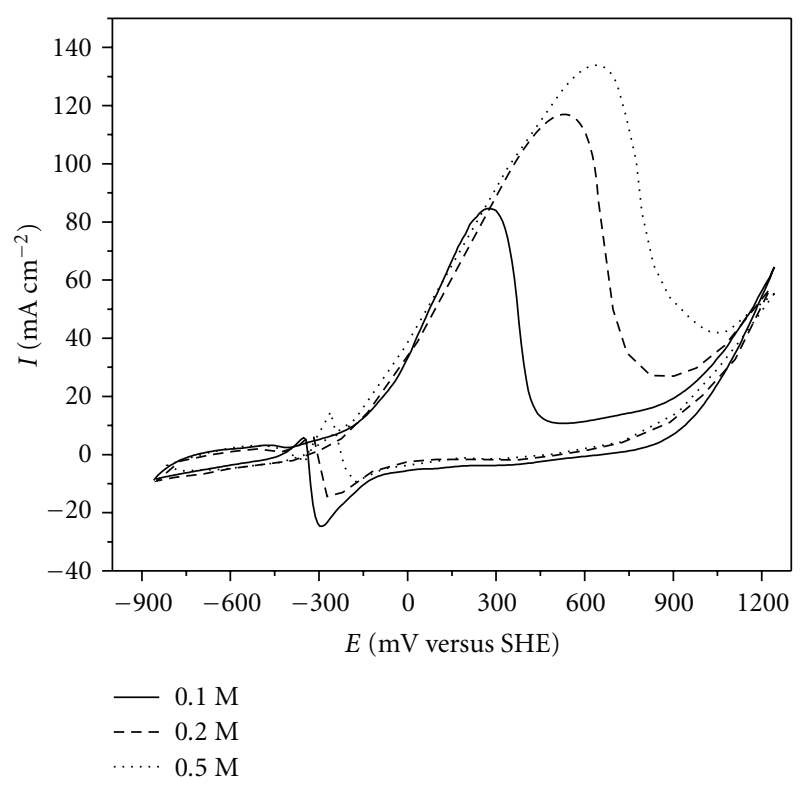

(a)

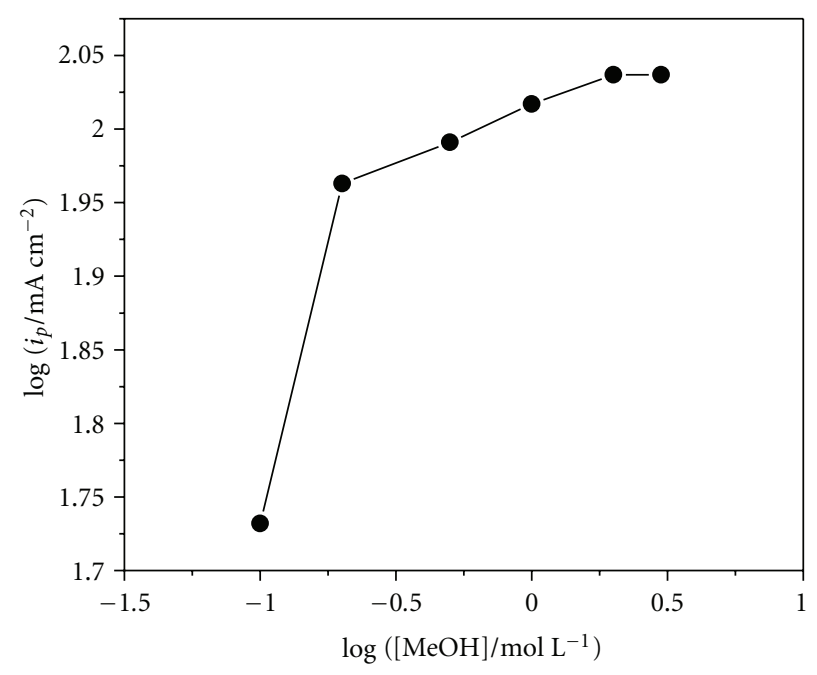

(c)

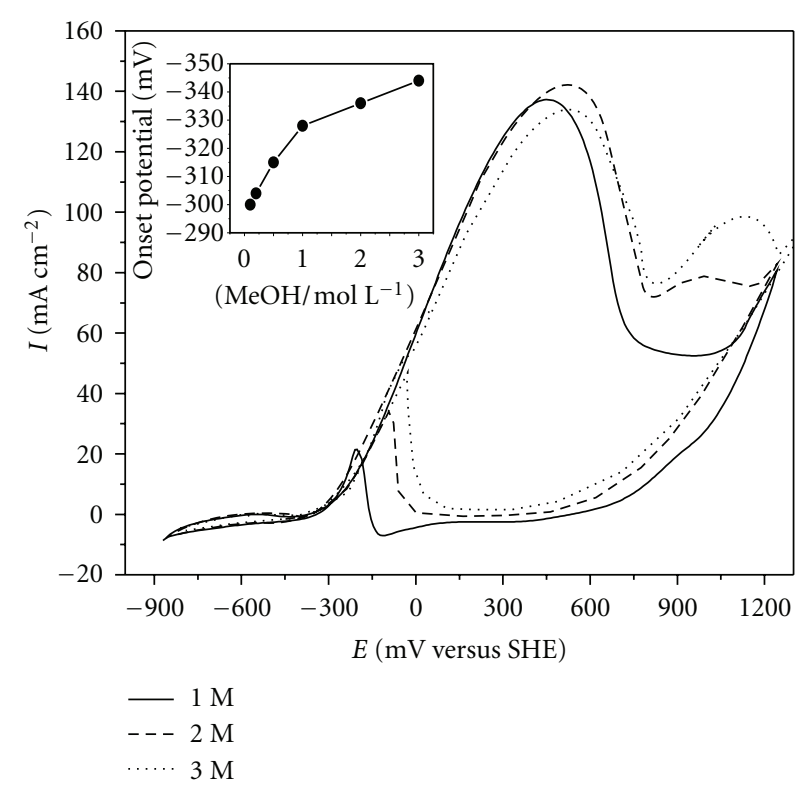

(b)

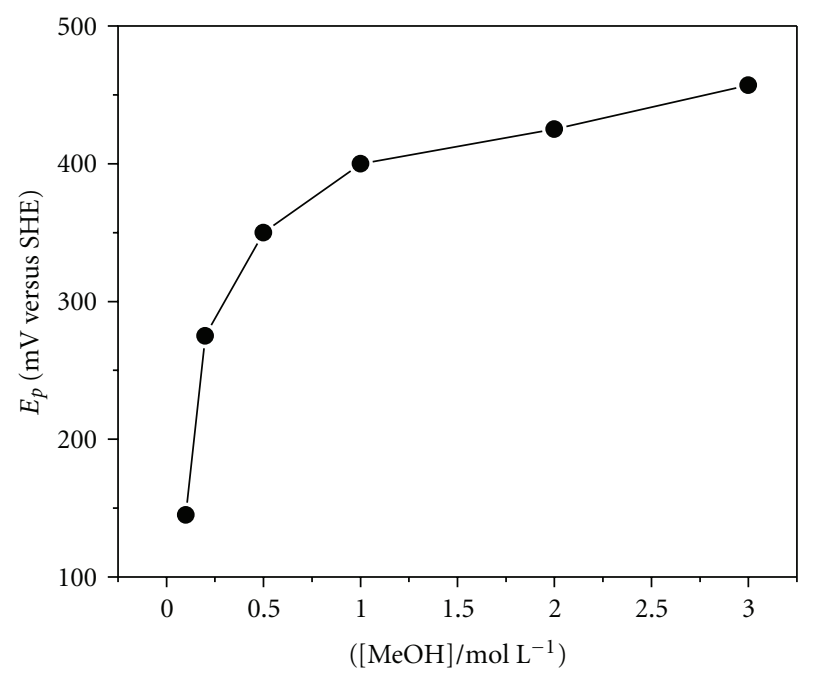

(d)

Figure 5: (a) and (b) Cyclic voltammograms for methanol oxidation on Pt-Pd/C electrode in $0.5 \mathrm{M} \mathrm{NaOH}$ at various methanol concentrations at $25^{\circ} \mathrm{C}$ and sweep rate of $50 \mathrm{mV} \mathrm{s}^{-1}$. (b-Inset) Variation of onset potentials for methanol oxidation with methanol concentration. (c) Plot of $\log i_{p}$ (peak current) versus $\log [\mathrm{MeOH}]$ for methanol oxidation on $\mathrm{Pt}-\mathrm{Pd} / \mathrm{C}$ electrode in $0.5 \mathrm{M} \mathrm{NaOH}$ with various methanol concentrations. (d) Variation of anodic peak potential $\left(E_{p}\right)$ for methanol oxidation on Pt-Pd/C catalyst with methanol concentration.

2.4. Electrochemical Measurements. Electrochemical measurements like cyclic voltammetry and chronoamperometry were carried out in the standard three-electrode cell at different temperature with the help of computer controlled AUTOLAB 30 Potentiostat/Galvanostat from Ecochemie B.V., The Netherlands. The working solutions were deaerated by purging with nitrogen (XL grade). Electrochemical impedance spectroscopy studies were conducted using the same AUTOLAB 30 PGSTAT with a frequency response ana- lyzer (FRA) module. EIS was performed with amplitude of $5 \mathrm{mV}$ for frequencies ranging from $40 \mathrm{kHz}$ to $100 \mathrm{mHz}$. Each scan contained about 100 data points (20 data points per decade). The impedance spectra were fitted to an equivalent circuit model using a nonlinear fitting program. A mercurymercuric oxide (MMO) reference electrode and a platinum foil $\left(2 \times 1 \mathrm{~cm}^{2}\right)$ counter electrode were used for all electrochemical experiments. The experiments were performed at different concentrations of $\mathrm{NaOH}$. Since the potential of the 


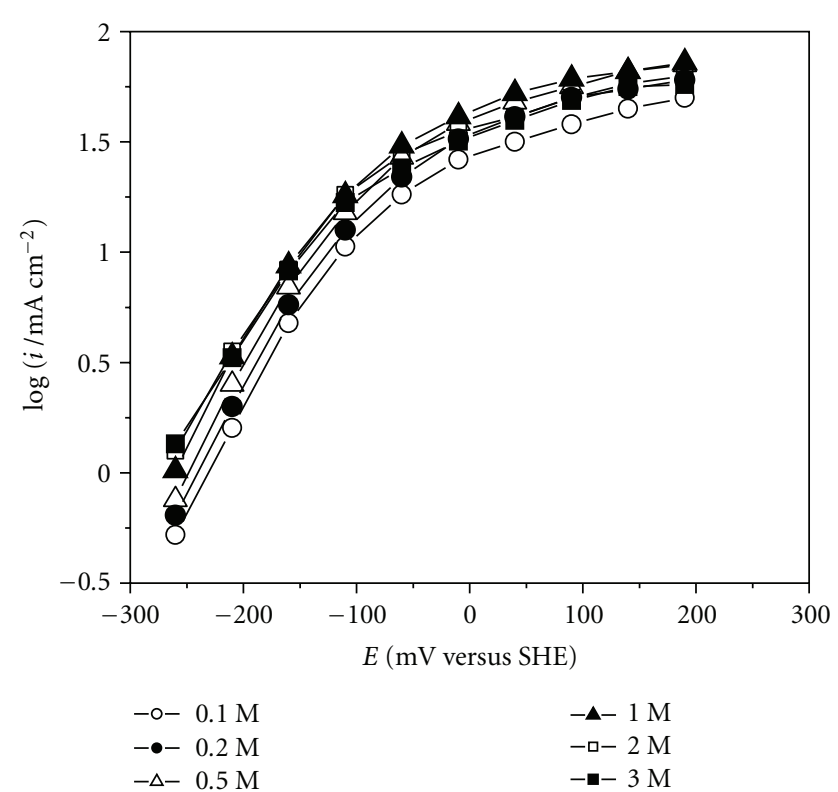

FIGURE 6: Potentiostatic polarization plots for methanol oxidation on Pt-Pd/C electrode in $0.5 \mathrm{M} \mathrm{NaOH}$ at various methanol concentrations at $25^{\circ} \mathrm{C}$.

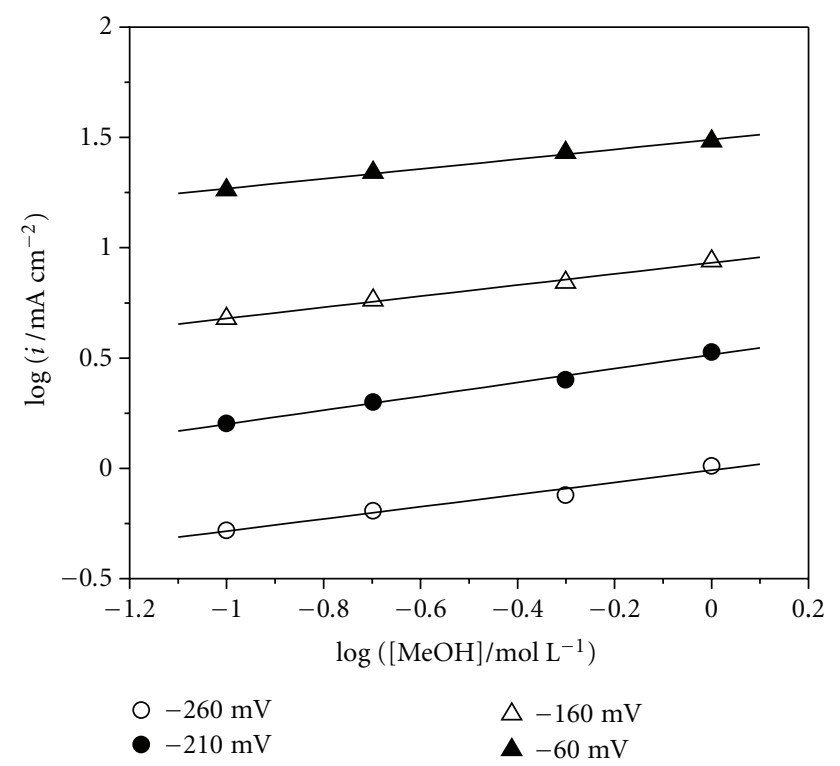

Figure 7: Dependence of methanol oxidation rate on methanol concentration in $0.5 \mathrm{M} \mathrm{NaOH}$ solution on $\mathrm{Pt}-\mathrm{Pd} / \mathrm{C}$ catalyst at different potentials.

MMO reference electrode depends on the activity of $\mathrm{OH}^{-}$, the potential correction was made by

$$
E=0.098-\frac{R T}{F} \ln \frac{\mathrm{a}_{\mathrm{OH}}{ }^{-}}{\mathrm{a}_{\mathrm{H}_{2} \mathrm{O}}^{1 / 2}}
$$

where $R$ is the universal gas constant; $T$ is the temperature; $F$ is the Faraday; $\mathrm{a}_{\mathrm{OH}^{-}}$and $\mathrm{a}_{\mathrm{H} 2 \mathrm{O}}$ are activities of $\mathrm{OH}^{-}$and $\mathrm{H}_{2} \mathrm{O}$, respectively. All the potentials in this paper are referenced to

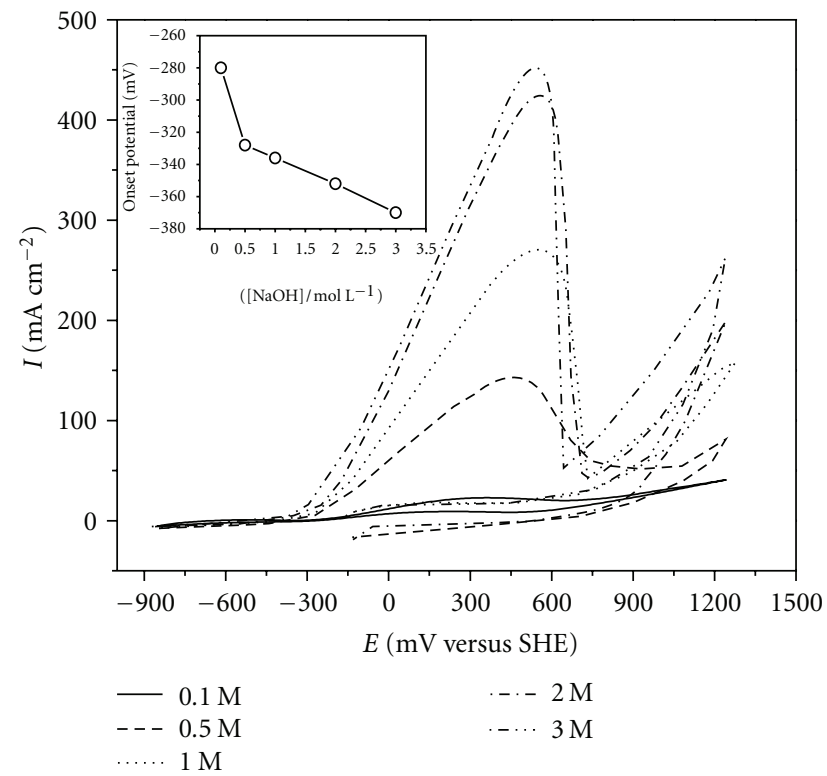

FIGURE 8: Cyclic voltammograms for methanol oxidation in $1.0 \mathrm{M}$ methanol at various $\mathrm{NaOH}$ concentrations on $\mathrm{Pt}-\mathrm{Pd} / \mathrm{C}$ catalyst at $25^{\circ} \mathrm{C}$ and sweep rate of $50 \mathrm{mV} \mathrm{s}^{-1}$; inset: variation of onset potentials for methanol oxidation with $\mathrm{NaOH}$ concentration in $1.0 \mathrm{M}$ methanol.

the standard hydrogen electrode (SHE) at cell operating temperature, and the current is normalized to the geometrical surface area.

\section{Results and Discussion}

3.1. Structural Characterization of Pt-Pd/C Electrocatalyst. The morphologies of the catalyst surface were studied using scanning electron microscopy. Pt-Pd particles show better dispersion than $\mathrm{Pt}$ on the graphite substrate shown in Figure 1. As platinum and palladium were coelectrodeposited on the graphite surface, both the metals were grown together on the same sphere making an assembly of adatoms in the form of agglomerated particles. The size of the particles does not show much variation and were found to remain within the range of $(80-100 \mathrm{~nm})$.

The Pt and Pd nanoparticles coelectrodeposited on graphite surface exhibited an XRD pattern of a typical facecenteredcubic-lattice structure as shown in Figure 2. The strong diffraction peaks at the Bragg angles of $40.08^{\circ}, 46.67^{\circ}$, $68.02^{\circ}, 82.08^{\circ}$, and $86.45^{\circ}$ correspond to the (111), (200), (220), (311), and (222) facets of Pt-Pd crystal. Alloying of $\mathrm{Pt}$ and Pd does not change the diffraction pattern. With the incorporation of $\mathrm{Pd}$ into the fcc structure of $\mathrm{Pt}$, the diffraction peaks were shifted to higher values of $2 \theta$, which is indicative of contraction of lattice. No characteristic peaks of Pt or Pd oxides were detected. The (111) peak was used to calculate the particle size of the Pt-Pd crystal according to the Debye-Scherrer equation. The average particle size in the Pt-Pd/C catalyst matrix was found to be $6.5 \mathrm{~nm}$. However, the morphology indicated agglomeration of smaller particles throughout the matrix. The bulk compositions 


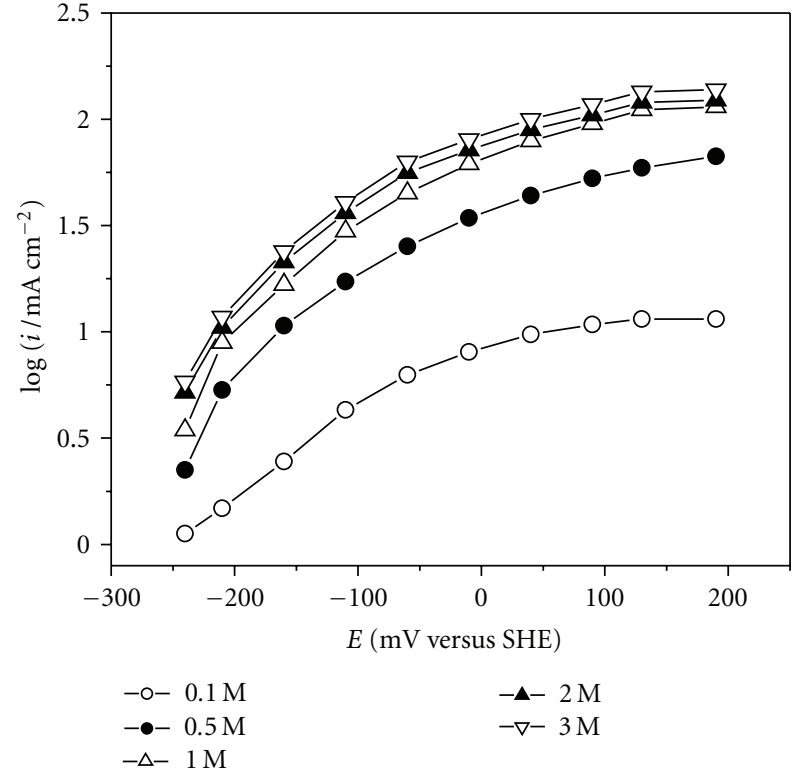

FIGURE 9: Potentiostatic polarization plots for methanol oxidation on $\mathrm{Pt}-\mathrm{Pd} / \mathrm{C}$ electrode in $1.0 \mathrm{M}$ methanol at various $\mathrm{NaOH}$ concentrations at $25^{\circ} \mathrm{C}$.

of electrocatalysts were investigated using energy dispersive $\mathrm{X}$-ray spectroscopy (EDX), and atomic ratio of Pt to Pd was found to be $1: 2$.

3.2. Comparison of Background Behavior for the $\mathrm{Pt} / \mathrm{C}, \mathrm{Pd} / \mathrm{C}$, and $\mathrm{Pt}-\mathrm{Pd} / \mathrm{C}$ Electrodes in Alkaline Medium. Figure 3 shows the cyclic voltammogram of $\mathrm{Pd} / \mathrm{C}, \mathrm{Pt} / \mathrm{C}$, and $\mathrm{Pt}-\mathrm{Pd} / \mathrm{C}$ electrodes in deoxygenated $0.5 \mathrm{M} \mathrm{NaOH}$ solution. Three peaks can be observed for $\mathrm{Pd} / \mathrm{C}$, which correspond to three electrochemical processes occurring on the surface of $\mathrm{Pd} / \mathrm{C}$. Peak a, which appears at $-360 \mathrm{mV}$, can be attributed to the adsorption of $\mathrm{OH}^{-}[43,44]$

$$
\mathrm{Pd}+\mathrm{OH}^{-} \longleftrightarrow \mathrm{Pd}-\mathrm{OH}_{\mathrm{ads}}+\mathrm{e}^{-} .
$$

Peak b, which emerges above ca. $-30 \mathrm{mV}$, can be attributed to the formation of Pd oxide layer

$$
\mathrm{Pd}-\mathrm{OH}_{\mathrm{ads}}+\mathrm{OH}^{-} \longleftrightarrow \mathrm{Pd}-\mathrm{O}+\mathrm{H}_{2} \mathrm{O}+\mathrm{e}^{-} \text {. }
$$

Peak c, at ca. $-266 \mathrm{mV}$, can be attributed to the corresponding reduction of $\mathrm{Pd}$ oxide to $\mathrm{Pd}$ during the cathodic sweep

$$
\mathrm{Pd}-\mathrm{O}+\mathrm{H}_{2} \mathrm{O}+\mathrm{e}^{-} \longleftrightarrow \mathrm{Pd}+2 \mathrm{OH}^{-} .
$$

In contrast, the $\mathrm{CV}$ of $\mathrm{Pt} / \mathrm{C}$ shows three potential peaks during the positive-going sweep as shown in the inset of the Figure 3. Peak $\mathrm{a}^{\prime}$ centering at $-568 \mathrm{mV}$ is due to the oxidation of the adsorbed hydrogen [45]

$$
\mathrm{Pt}-\mathrm{H}_{\mathrm{ads}}+\mathrm{OH}^{-} \longleftrightarrow \mathrm{Pt}+\mathrm{H}_{2} \mathrm{O}+\mathrm{e}^{-} .
$$

Peak $\mathrm{b}^{\prime}$, which emerges above $-350 \mathrm{mV}$, can be attributed to the adsorption of $\mathrm{OH}^{-}$

$$
\mathrm{Pt}+\mathrm{OH}^{-} \longleftrightarrow \mathrm{Pt}-\mathrm{OH}_{\mathrm{ads}}+\mathrm{e}^{-} .
$$

Peak $c^{\prime}$, can be attributed to the formation of Pt oxide layer which emerges above ca. $190 \mathrm{mV}$

$$
\mathrm{Pt}-\mathrm{OH}_{\mathrm{ads}}+\mathrm{OH}^{-} \longleftrightarrow \mathrm{Pt}-\mathrm{O}+\mathrm{H}_{2} \mathrm{O}+\mathrm{e}^{-} \text {. }
$$

The adsorption of $\mathrm{OH}^{-}$starts at the more negative potential on $\mathrm{Pd} / \mathrm{C}$ electrode than on the $\mathrm{Pt} / \mathrm{C}$ electrode and overlaps the hydrogen desorption peak.

Peak $\mathrm{d}^{\prime}$, centering at $-215 \mathrm{mV}$, can be attributed to the reduction of the $\mathrm{Pt}(\mathrm{II})$ oxide during the cathodic sweep such as

$$
\mathrm{Pt}-\mathrm{O}+\mathrm{H}_{2} \mathrm{O}+\mathrm{e}^{-} \longleftrightarrow \mathrm{Pt}+2 \mathrm{OH}^{-} \text {. }
$$

A small hydrogen adsorption peak, $\mathrm{e}^{\prime}$, appears at $-625 \mathrm{mV}$ with the $\mathrm{Pt} / \mathrm{C}$ electrode, which is not clearly visible for $\mathrm{Pd} / \mathrm{C}$ electrode. At the $\mathrm{Pd} / \mathrm{C}$ surface, hydrogen adsorption and absorption occur simultaneously. The hydrogen adsorption occurs on the Pt surface as follows:

$$
\mathrm{Pt}+\mathrm{H}_{2} \mathrm{O}+\mathrm{e} \longleftrightarrow \mathrm{Pt}-\mathrm{H}_{\mathrm{ads}}+\mathrm{OH}^{-} \text {. }
$$

The feature of Pt-Pd/C catalyst demonstrated both the characteristics of $\mathrm{Pd} / \mathrm{C}$ and $\mathrm{Pt} / \mathrm{C}$ and the difference of the potentiodynamic curve for $\mathrm{Pt}-\mathrm{Pd} / \mathrm{C}$ catalyst indicates the formation of an alloy of these metals. The X-ray analysis also supports this fact. For the Pt-Pd/C alloyed electrode, the hydrogen desorption as well as $\mathrm{OH}^{-}$adsorption peaks overlaps and appears as a single peak, $\mathrm{a}^{\prime \prime}$, at $-340 \mathrm{mV}$. The $\mathrm{OH}^{-}$ adsorption clearly dominates in this region and starts around $-730 \mathrm{mV}$. The presence of Pd facilitates the adsorption of $\mathrm{OH}^{-}$and suppress the hydrogen desorption. The board peak in the potential region -730 and $-170 \mathrm{mV}$ can be attributed to the hydrogen desorption and $\mathrm{OH}^{-}$adsorption

$$
\begin{gathered}
\mathrm{M}-\mathrm{H}_{\mathrm{ads}}+\mathrm{OH}^{-} \longleftrightarrow \mathrm{M}+\mathrm{H}_{2} \mathrm{O}+\mathrm{e}^{-}, \\
\mathrm{M}+\mathrm{OH}^{-} \longleftrightarrow \mathrm{M}-\mathrm{OH}_{\mathrm{ads}}+\mathrm{e}^{-},
\end{gathered}
$$

M stand for Pt-Pd.

The double layer region for $\mathrm{Pt}-\mathrm{Pd} / \mathrm{C}$ is more compressed, and oxide formation starts at lower potential ca. $-165 \mathrm{mV}$. The appearance of single oxide formation as well as reduction peak is in accordance with alloyed behavior of the Pt-Pd. The Pt-Pd/C electrodes deliver oxide reduction peak, $\mathrm{c}^{\prime \prime}$, at ca. $-395 \mathrm{mV}$. The oxide formation and reduction reactions on the $\mathrm{Pt}-\mathrm{Pd} / \mathrm{C}$ surface can be represented by

$$
\begin{gathered}
\mathrm{M}-\mathrm{OH}_{\mathrm{ads}}+\mathrm{OH}^{-} \longleftrightarrow \mathrm{M}-\mathrm{O}+\mathrm{H}_{2} \mathrm{O}+\mathrm{e}^{-}, \\
\mathrm{M}-\mathrm{O}+\mathrm{H}_{2} \mathrm{O}+\mathrm{e}^{-} \longleftrightarrow \mathrm{M}+2 \mathrm{OH}^{-} .
\end{gathered}
$$

The hydrogen adsorption peak, $\mathrm{d}^{\prime \prime}$, appears at around $-760 \mathrm{mV}$, and the corresponding reaction is as follows:

$$
\mathrm{M}+\mathrm{H}_{2} \mathrm{O}+\mathrm{e} \longleftrightarrow \mathrm{M}-\mathrm{H}_{\mathrm{ads}}+\mathrm{OH}^{-} .
$$

The advantage of $\mathrm{Pt}-\mathrm{Pd} / \mathrm{C}$ catalyst in alkaline medium is clearly visible from the remarkable negative shift of hydrogen adsorption/desorption $\left(\mathrm{H}_{\mathrm{ad}} / \mathrm{H}_{\mathrm{des}}\right)$ and oxide formation/reduction peak as compared to $\mathrm{Pd} / \mathrm{C}$ and $\mathrm{Pt} / \mathrm{C}$. 
The CVs (Figure 3) were used for the estimation of the electrochemically active surface area (ECSA) of the synthesized catalysts in alkaline medium. The high charge corresponding to the hydrogen adsorption/desorption and oxide reduction peak on $\mathrm{Pt}-\mathrm{Pd} / \mathrm{C}$ catalyst is indicative of very high ECSA compared to $\mathrm{Pd} / \mathrm{C}$ and $\mathrm{Pt} / \mathrm{C}$ [46]. The ECSA of the $\mathrm{Pd} / \mathrm{C}$ electrodes was measured by determining the coulombic charge $(Q)$ for the reduction of palladium oxide and using the relation

$$
\mathrm{ECSA}=\frac{Q}{S L},
$$

where " $S$ " is the proportionality constant used to relate charge with area and " $l$ " is the catalyst loading in " $g$ ". The charge required for the reduction of $\mathrm{PdO}$ monolayer is assumed as $405 \mathrm{mC} \mathrm{cm}^{-2}$ [47].

The ECSA of the Pt/C catalyst was determined by measuring the charge collected in the hydrogen adsorption/ desorption region $\left(Q_{H}\right)$ after double-layer correction and assuming a value of $\left(Q_{\text {ref }}=210 \mu \mathrm{C} \mathrm{cm}^{-2}\right)$ the charge needed for oxidation of a single layer of hydrogen on a smooth $\mathrm{Pt}$ surface [48]. Then, the specific ECSA was calculated based on the following relation:

$$
\mathrm{ECSA}=\frac{Q_{H}}{Q_{\mathrm{ref}} l},
$$

where " $l$ " is the Pt loading in " $g$ ".

For $\mathrm{Pt}-\mathrm{Pd} / \mathrm{C}$ catalyst the ECSA was measured by determining the coulombic charge $(Q)$ corresponding to the oxide reduction peak. However, it is not possible to measure ECSA value accurately by using this method, because the reduction peaks may be ascribed to the reduction of the oxides of $\mathrm{Pd}$ and $\mathrm{Pt}$ formed on the surface of the Pt-Pd/C catalyst during the positive scan. [49]. The charge required for the reduction of $\mathrm{PdO}$ ( $\mathrm{q}_{\mathrm{PdO}-\mathrm{red}}$ ) and $\mathrm{PtO}\left(\mathrm{q}_{\mathrm{PdO}}-\mathrm{red}\right)$ monolayer were assumed as 405 and $420 \mu \mathrm{C} \mathrm{cm}^{-2}$, respectively [48, 50]. For the $\mathrm{Pt}-\mathrm{Pd} / \mathrm{C}$ catalyst having $\mathrm{Pt}$ to $\mathrm{Pd}$ ratio $(1: 2)$, the mean value of charge required for oxide reduction was calculated as $410 \mu \mathrm{C} \mathrm{cm}^{-2}$ and used for the calculation of ECSA of the alloyed catalyst. The high charge corresponding to the hydrogen adsorption and oxygen reduction peak particularly on $\mathrm{Pt}-\mathrm{Pd} / \mathrm{C}$ catalyst which is indicative of very high electroactive surface area (ECSA) compared to $\mathrm{Pt} / \mathrm{C}$ and $\mathrm{Pd} / \mathrm{C}$ $[46,51]$.

The value of ECSA for Pt-Pd/C was found to be far high $\left(51.4 \mathrm{~m}^{2} \mathrm{~g}^{-1}\right)$, about 15 and 5.8 times higher than the value obtained for Pt/C $\left(3.4 \mathrm{~m}^{2} \mathrm{~g}^{-1}\right)$ and $\mathrm{Pd} / \mathrm{C}\left(8.8 \mathrm{~m}^{2} \mathrm{~g}^{-1}\right)$. The high ECSA of Pt-Pd/C catalyst could be attributed to the smaller particle size and more uniform size dispersion.

3.3. Comparison of Methanol Oxidation on $\mathrm{Pd} / \mathrm{C}, \mathrm{Pt} / \mathrm{C}$, and $\mathrm{Pt}-\mathrm{Pd} / \mathrm{C}$ Electrodes in $\mathrm{NaOH}$ Solution. The chemical nature and the structure of the electrode material play a key role in the adsorption and electro-oxidation of aliphatic alcohols. The chemisorption on the catalyst surface is one of the prime factors affecting the electrocatalytic activity. This is illustrated by the electro-oxidation of methanol under potentiodynamic conditions in alkaline medium in the voltammograms corresponding to $\mathrm{Pd} / \mathrm{C}, \mathrm{Pt} / \mathrm{C}$, and $\mathrm{Pt}-\mathrm{Pd} / \mathrm{C}$ electrodes. Figure 4 shows the cyclic voltammograms $(\mathrm{CV})$ of

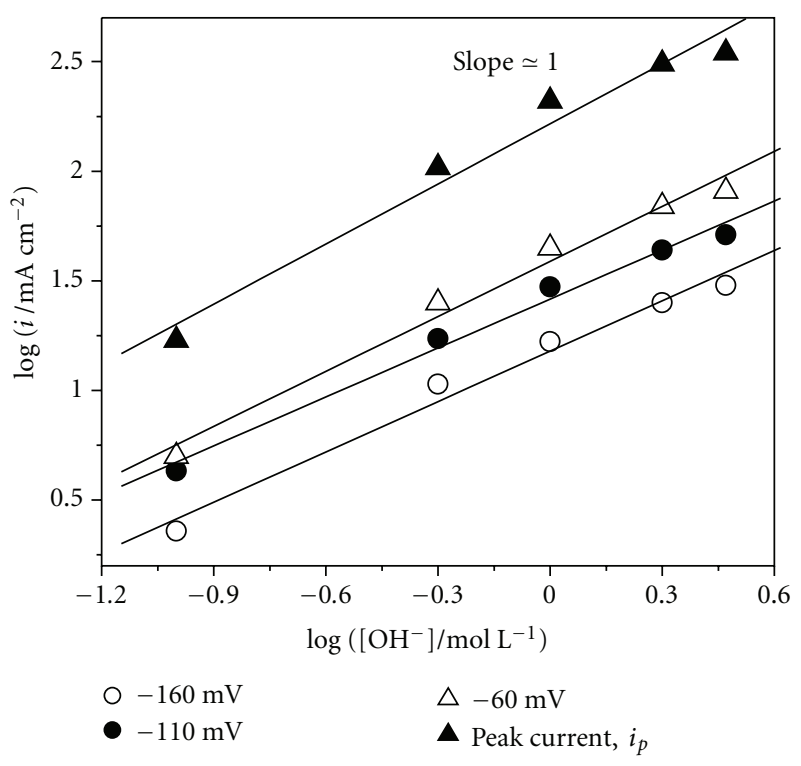

FIgURE 10: Dependence of methanol oxidation rate on $\mathrm{NaOH}$ concentration in $1.0 \mathrm{M}$ methanol with various $\mathrm{NaOH}$ concentrations on Pt-Pd/C catalyst at different potentials.

methanol oxidation recorded in the solution containing 1.0 $\mathrm{M}$ methanol and $0.5 \mathrm{M} \mathrm{NaOH}$ on different electrodes at a scan rate of $50 \mathrm{mV} \mathrm{s}^{-1}$. The $\mathrm{Pt}-\mathrm{Pd} / \mathrm{C}$ catalyst shows lower onset potential for methanol oxidation and a large anodic peak current density $\left(130 \mathrm{~mA} \mathrm{~cm}^{-2}\right)$ compared to $\mathrm{Pt} / \mathrm{C}\left(100 \mathrm{~mA} \mathrm{~cm}^{-2}\right)$ and $\mathrm{Pd} / \mathrm{C}\left(40 \mathrm{~mA} \mathrm{~cm}^{-2}\right)$. The lower onset potential (magnified in the inset of Figure 4) indicates that methanol oxidation commences at lower potential on $\mathrm{Pt}-\mathrm{Pd} / \mathrm{C}(-360 \mathrm{mV})$ than $\mathrm{Pt} / \mathrm{C}(-345 \mathrm{mV})$ and $\mathrm{Pd} / \mathrm{C}$ $(-350 \mathrm{mV})$, respectively. Thus, $\mathrm{Pt}-\mathrm{Pd} / \mathrm{C}$ electrode demonstrates a much higher catalytic activity towards the methanol oxidation, probably due to the fact that alloying of Pd with $\mathrm{Pt}$ is capable of controlling the poisoning effect and selected as the working electrode in course of studying the electrooxidation kinetics of methanol.

The inset of the Figure 4 illustrates the methanol oxidation under potentiodynamic conditions on $\mathrm{Pt}-\mathrm{Pd} / \mathrm{C}$ in the solution containing $0.5 \mathrm{M} \mathrm{NaOH}$ and $1.0 \mathrm{M} \mathrm{MeOH}$ which has been superimposed with the basic voltammogram for the alkaline solution only. A detailed cyclic voltammetric study on the Pt-Pd/C electrode shows that in blank $\mathrm{NaOH}$ solution, a visible hydrogen adsorption/desorption peak of current density $3 \mathrm{~mA} \mathrm{~cm}^{-2}$ appeared at potential around $-400 \mathrm{mV}$. The broad second oxidation peak at potential $\sim 200 \mathrm{mV}$ was attributed to the formation of metal oxide [22, 52]. A methanol oxidation peak was clearly observed in the $\mathrm{CV}$ of $\mathrm{Pt}-\mathrm{Pd} / \mathrm{C}$ electrode in the presence of $1.0 \mathrm{M}$ methanol at potential $\sim 700 \mathrm{mV}$, and the oxide formation peak was suppressed by this large current of methanol oxidation. The electro-oxidation of methanol was characterized by two welldefined current peaks on the forward and reverse scans. In the forward scan, the oxidation peak corresponds to the oxidation of freshly chemisorbed species coming from the alcohol adsorption. The reverse scan peak is primarily associated with the removal of carbonaceous species formed 


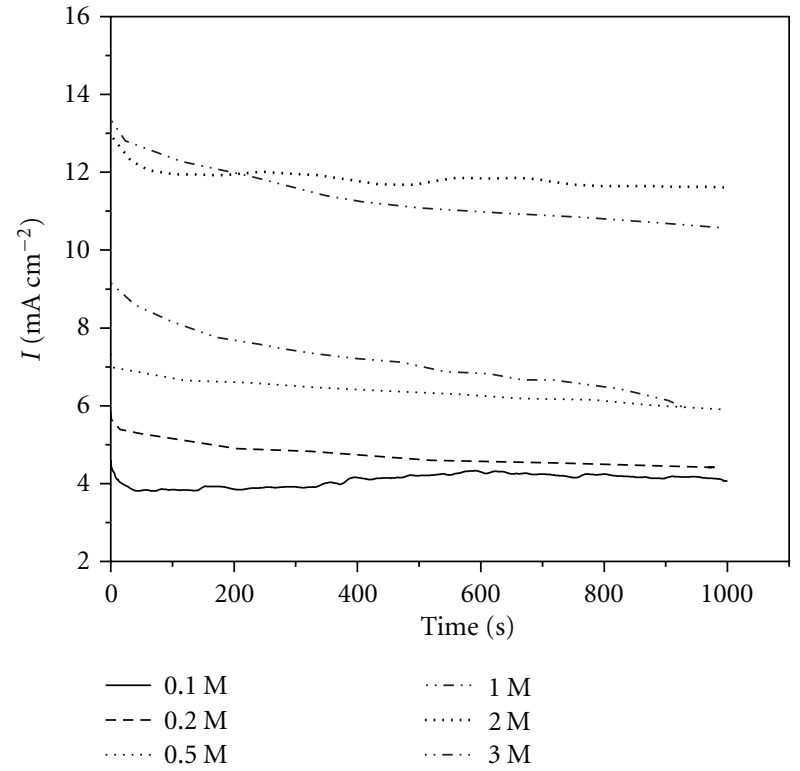

FIgURE 11: Chronoamperometric curves for methanol oxidation at $-160 \mathrm{mV}$ on $\mathrm{Pt}-\mathrm{Pd} / \mathrm{C}$ catalyst in $0.5 \mathrm{M} \mathrm{NaOH}$ containing various concentrations of methanol.

during the oxidation of freshly chemisorbed species in the forward scan $[53,54]$. The magnitude of the peak current on the forward scan indicates the electrocatalytic activity of the $\mathrm{Pt}-\mathrm{Pd} / \mathrm{C}$ electrode for oxidation reaction of methanol. The initial small current density peak $\left(5 \mathrm{~mA} \mathrm{~cm}^{-2}\right)$ in the hydrogen desorption region in the presence of methanol is attributed to the combined effect of hydrogen desorption and the dissociative adsorption of methanol in this potential region. A small oxide reduction peak was observed in the reverse scan in the absence of methanol, while the same was not prominent in presence of methanol. The presence of unoxidized organic residue suppresses the oxide reduction peak during reverse scan.

\subsection{Effect of Methanol Concentration on Methanol Oxidation.} Cyclic voltammograms for the methanol oxidation on $\mathrm{Pt}$ $\mathrm{Pd} / \mathrm{C}$ electrode in $0.5 \mathrm{M} \mathrm{NaOH}$ are displayed in Figures 5(a) and 5(b) for different concentration of methanol. For low concentration of methanol $(0.1 \mathrm{M})$, the oxide formation and their reduction peaks were observed along with the feeble hydrogen adsorption/desorption peaks still visible, implying that methanol does not prevent completely the hydrogen adsorption. The formation of metal oxide gives rise to nearly inhibition of methanol oxidation, and a decreasing trend in current was observed [55]. This is also because of the deactivation of the electrode surface by poisoning species and the shortage of methanol close to the electrode surface due to the oxidation. But as the electrode surface was reactivated by reduction of metal oxide in the reverse scan, the renewed oxidation became prominent. The magnitude of hydrogen adsorption/desorption were reduced as the concentration of methanol increases, implying that methanol is adsorbed preferentially on the electrode surface at this potential $[55,56]$. A second anodic oxidation peak was observed at methanol concentration as high as 2.0 and $3.0 \mathrm{M}$. This reflects the possibility of oxidation of organic residue produced at high concentration of methanol. The increase in the concentration of methanol results in an increase in anodic peak current in the forward scan up to the concentration $1.0 \mathrm{M}$, and beyond that concentration, the increase in anodic peak current becomes negligible. This behavior may be explained by a shift from a diffusion-controlled reaction at low methanol concentration to reaction, which is inhibited by adsorbed reaction intermediates at higher concentrations and insufficient availability of $\mathrm{OH}^{-}$in the solution [57]. Figure 5(c) demonstrates a plateau in the plot of the peak current density versus $\log [\mathrm{MeOH}]$ at concentration greater than approximately $1.0 \mathrm{M}$. The figure reveals that methanol oxidation peak current increases with increasing methanol concentration up to $1.0 \mathrm{M}$, after which they reach almost a constant value independent of the concentration. Thus, a concentration value of $1.0 \mathrm{M}$ represents a critical concentration after which the adsorption of oxidation products at the electrode surface causes the hindrance to further oxidation. At higher concentration of methanol, diffusion control reaction can no longer occur, and the reaction is inhibited by adsorbed reaction intermediates. Diffusion control reaction with respect to methanol occurs when $\mathrm{OH}^{-}$ions are available in excess and chemisorbed methanol species is insufficient [57]. Thus, at lower methanol concentration, when methanol $/ \mathrm{OH}^{-}$ratio $\leq 1$, the peak current in the voltammograms was controlled by the diffusion transport of methanol due to excess availability of $\mathrm{OH}^{-}$. At higher methanol concentrations, methanol $/ \mathrm{OH}^{-}$ratio $>1$, the peak current in voltammograms were controlled by the diffusion transport of $\mathrm{OH}^{-}$ions because of excess production of reaction intermediates and insufficient availability of $\mathrm{OH}^{-}$ions compared to methanol. However, maximum peak current was observed with equimolar proportion of $\mathrm{OH}^{-}$and methanol in solution. It is clearly observed that the anodic peak current with increasing methanol concentration levels off at concentration higher than $1.0 \mathrm{M}$. This effect may be assumed due to the saturation of active sites on the surface of the electrode. In accordance with this result, the optimum concentration of methanol may be considered to be $1.0 \mathrm{M}$ to achieve a reasonably high current density of oxidation. An increase in reverse oxidation peak current and a positive shift of both forward and reverse oxidation peak potential was encountered. This phenomenon can be explained by the increase in concentration of the unoxidized organic residue with the increase in the concentration of methanol and require higher potential to oxidize this strongly adsorbed residue. Figure 5(d) represents the dependence of anodic peak potential $\left(E_{p}\right)$ of methanol oxidation on the bulk concentration of methanol. The relation between methanol concentration and the oxidation peak potential may be attributed to the IR drop due to high oxidation current at higher concentrations [25]. However, the overall process is not a case of single kinetic control but rather is more complicated with a series of competing reactions. The broadening of methanol oxidation peak with the increase of methanol concentration is due to the accumulation of methanol molecules on the catalyst surface that require higher potential to oxidize 
though oxidation starts more or less at the same potential. The diminishing trend of the oxide formation as well as the reduction peak is due to higher concentration of methanol that suppresses both the peaks. The inset of Figure 5(b) shows the variation of onset potential with the concentration of methanol. A small negative shift of the onset potential was observed with the increase in methanol concentration and is attributed to the increased rate of methanol adsorption at the catalyst surface with adequate supply of methanol molecules. This behavior is also reflected in Figure 6, which shows a nonlinear behavior in the potentiostatic polarization plot at high anodic potential.

The reaction order for methanol in the methanol oxidation reaction was determined by plotting $\log i$ versus $\log$ $[\mathrm{MeOH}]$ up to methanol concentration of $1.0 \mathrm{M}$ at a selected low potential region of $-260 \mathrm{mV}$ to $-60 \mathrm{mV}$ as presented in Figure 7 . The order with respect to methanol was derived from the relation

$$
\begin{gathered}
\text { Rate } \equiv i=k C^{n}, \\
\log (i)=\log k+n \log C,
\end{gathered}
$$

where, " $i$ " is the current density, $k$ is the reaction rate constant, $C$ is the bulk concentration of methanol, and " $n$ " is the reaction order. A slope of 0.45 was obtained, which was independent of the potential. A reaction order close to 0.5 is also reported in alkaline solution on platinized Ti mesh electrode which suggested that the adsorption of methanol and intermediates on $\mathrm{Pt}-\mathrm{Pd} / \mathrm{C}$ electrode followed a Temkin-type isotherm in the Tafel region $[25,57]$. Higher concentration of methanol was avoided, because at higher concentration, the presence of other adsorbed intermediate species makes the oxidation of methanol more complicated. Partial oxidation of $\mathrm{CH}_{3} \mathrm{OH}$ leads to the formation of $(\mathrm{HCO})_{\text {ads }}$ as the intermediate by

$$
\mathrm{CH}_{3} \mathrm{OH}+3 \mathrm{OH}^{-} \stackrel{k_{1}}{\longrightarrow} \mathrm{HCO}_{\mathrm{ad}}+3 \mathrm{H}_{2} \mathrm{O}+3 \mathrm{e}^{-}
$$

and the coverage of intermediate $\mathrm{HCO}_{\text {ads }}$ can be expressed in terms of methanol concentration as

$$
\theta_{\mathrm{HCO}}=k_{1} C_{\mathrm{CH}_{3} \mathrm{OH}}^{0.45}
$$

\subsection{Effect of $\mathrm{NaOH}$ Concentration on Methanol Oxidation.} The influence of the hydroxide concentration on the oxidation of methanol, in alkaline medium on $\mathrm{Pt}-\mathrm{Pd} / \mathrm{C}$ electrode, was studied by recording CVs in solution containing $1.0 \mathrm{M}$ methanol and $x \mathrm{MNaOH}$, with $x$ ranging between 0.1 and 2.0 M. Typical CVs at a scan rate of $50 \mathrm{mV} \mathrm{s}^{-1}$ are shown in Figure 8. The current density increases rapidly with $\mathrm{OH}^{-}$ concentration at the same methanol concentration. The magnitude of reverse oxidation peak current density is much less than the anodic peak current density. This is suggestive of the trend towards complete oxidation of methanol at higher concentration of $\mathrm{OH}^{-}$when only a small amount of methanolic residue may be left on the electrode surface. The reaction proceeds further on the surfaces covered by reversible $\mathrm{OH}_{\text {ad }}$ species, showing relatively faster kinetics.

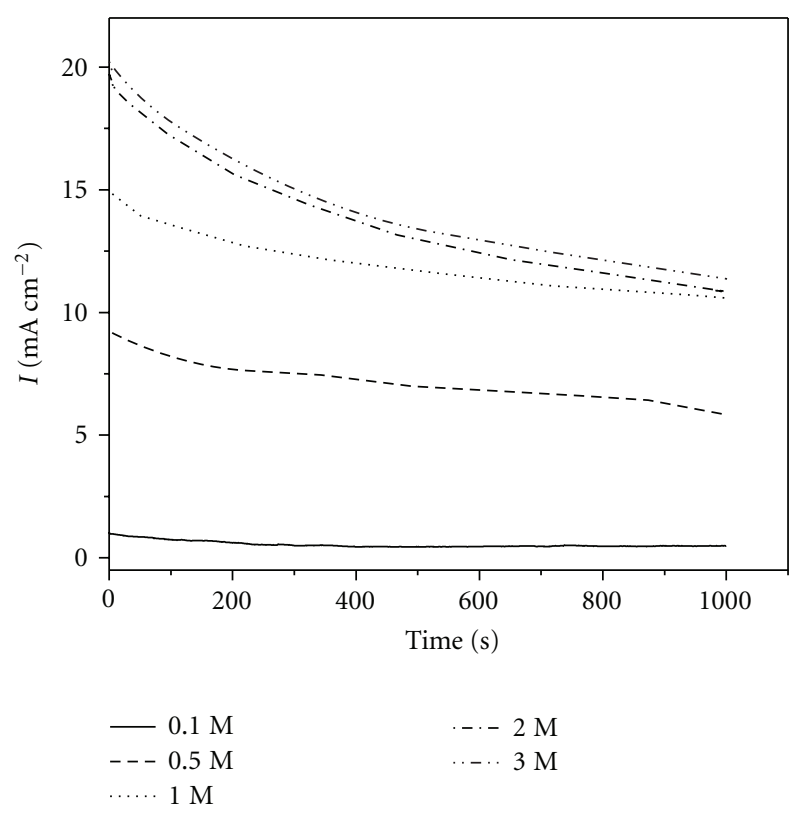

FIGURE 12: Chronoamperometric curves for methanol oxidation at $-160 \mathrm{mV}$ on $\mathrm{Pt}-\mathrm{Pd} / \mathrm{C}$ catalyst in $1.0 \mathrm{M} \mathrm{MeOH}$ containing various concentration of $\mathrm{NaOH}$.

The current maxima are attained at the potentials $\left(E_{p}\right)$, where the reaction kinetics is optimized by the balance between the rate of methanol dehydrogenation and the rate of oxidation of dehydrogenated products with $\mathrm{OH}_{\text {ads }}$ species [58]. The balance is rapidly disturbed immediately after reaching the maximum reaction rate, probably due to the fast transition from the reversible to the irreversible state of oxygenated species. The lowering of onset potential for methanol oxidation was observed with the increase in the concentration of $\mathrm{NaOH}$ and is shown in the inset of Figure 8. This behavior also suggests that the kinetics of methanol oxidation was enhanced by the availability of $\mathrm{OH}^{-}$ions in solution in ample quantity and higher $\mathrm{OH}^{-}$ ion coverage on the electrode surface [57]. It was found that $0.5-1.0 \mathrm{M} \mathrm{NaOH}$ appears to contribute to the effective electrocatalytic performance of $\mathrm{Pt}-\mathrm{Pd} / \mathrm{C}$ electrode as an optimal $\mathrm{pH}$ condition. Tafel plots for the methanol oxidation reaction for a range of $\mathrm{NaOH}$ concentration are given in Figure 9. At concentration greater than $0.5 \mathrm{M} \mathrm{NaOH}$, the Tafel slopes were identical $\left(125 \mathrm{mV} \mathrm{dec}^{-1}\right)$ and suggest that the same reaction mechanism occurs throughout this $\mathrm{pH}$ range. At very low concentration of $\mathrm{NaOH}(0.1 \mathrm{M})$, the Tafel slope increased to $266 \mathrm{mV} \mathrm{dec}{ }^{-1}$, showing poor reactivity at lower $\mathrm{pH}$ condition. Figure 10 shows the dependence of $\log i$ versus $\log [\mathrm{NaOH}]$ at several fixed potentials in the linear region of the Tafel plots of $\mathrm{Pt}-\mathrm{Pd} / \mathrm{C}$ catalysts. The reaction order for $\mathrm{OH}^{-}$, obtained from the slope of the $\log i$ versus $\log \left[\mathrm{OH}^{-}\right]$plot, was 0.7 and was independent of the potential within the Tafel potential range. However, the plot of $\log i_{p}$ versus $\log \left[\mathrm{OH}^{-}\right]$gave slope close to 1.0. This behavior was also observed with methanol oxidation on $\mathrm{Pt}$ and platinised Ti mesh electrode in alkaline medium [57, 58]. The fractional reaction order for $\mathrm{OH}^{-}$in Tafel region 


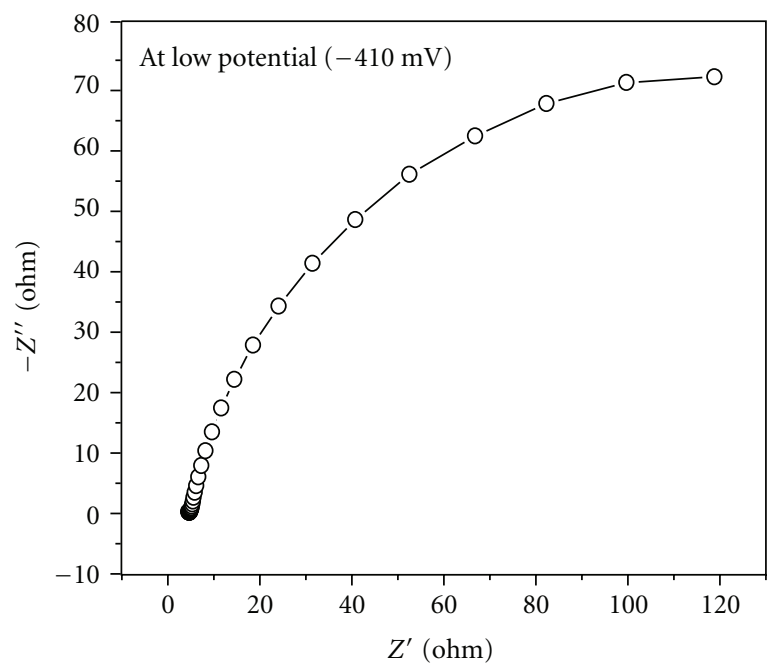

(a)

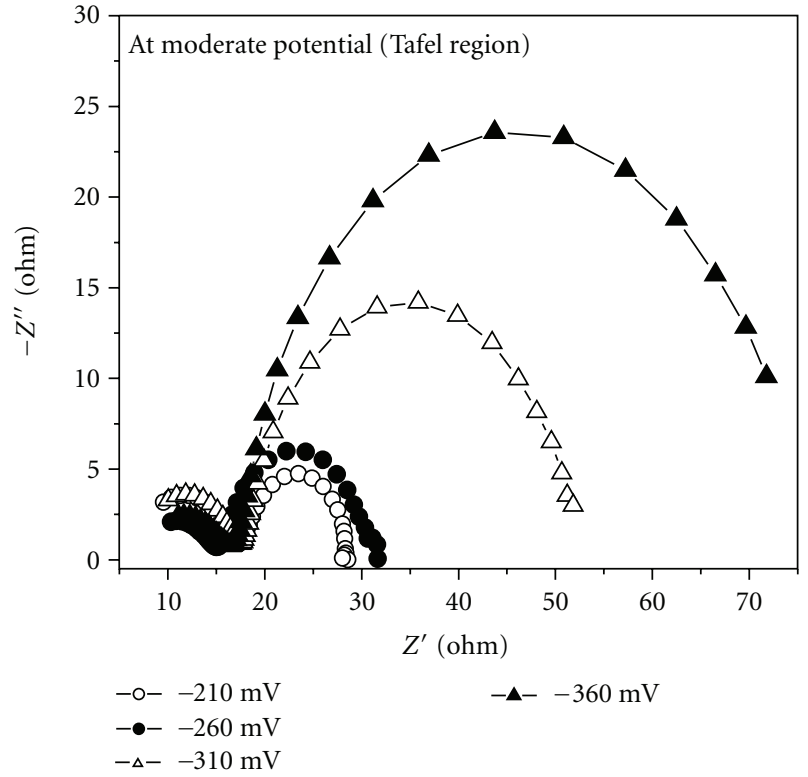

(b)

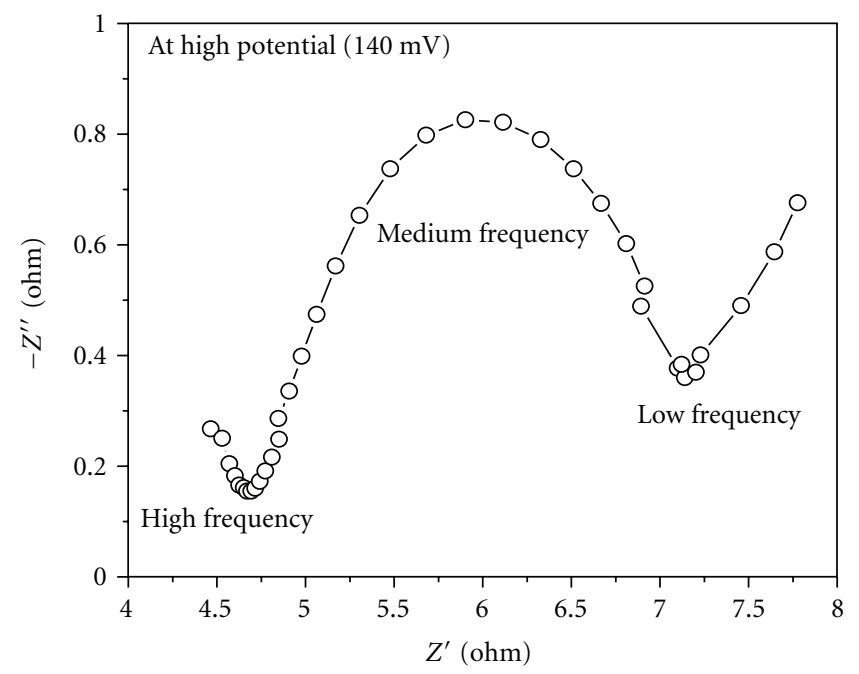

(c)

Figure 13: Impedance spectra for methanol oxidation on Pt-Pd/C catalyst at different potentials in a solution containing $0.5 \mathrm{M} \mathrm{NaOH}$ and $1.0 \mathrm{M}$ methanol.

implies that adsorption of $\mathrm{OH}^{-}$on the electrode follows Temkin type isotherms. The energy of adsorption at any adsorption site depends on whether or not its neighbors are already occupied. It is assumed that the rate-determining step involves adsorption of $\mathrm{OH}_{\mathrm{ad}}$ as well as that of the intermediate $\mathrm{HCO}_{\mathrm{ad}}[58]$

$$
\mathrm{HCO}_{\mathrm{ad}}+\mathrm{OH}_{\mathrm{ad}} \stackrel{k}{\longrightarrow} \mathrm{HCOOH} \text {. }
$$

The fractional coverage can be expressed as

$$
\begin{aligned}
& \mathrm{OH}^{-} \longleftrightarrow \mathrm{OH}_{\mathrm{ad}}+\mathrm{e}^{-}, \\
& \theta_{\mathrm{OH}}=k_{1} C_{\mathrm{OH}}^{0.5} e^{\alpha F \eta / R T},
\end{aligned}
$$

where $k_{1}$ is rate constant, $\alpha$ is transfer coefficient and $\eta$ is the over potential. The different reaction order at the peak current density and in the Tafel region suggests different reaction process occurs in these two potential regions. Thus, the $\mathrm{OH}$ adsorption on the electrode is dependent on the potential.

\subsection{Current-Time (Chronoamperometric) Behavior for Meth- anol Electro-Oxidation}

3.6.1. Effect of Methanol Concentration. Current-time transient curve were recorded over a period of time in order to 
characterize the stability of methanol oxidation reaction on the $\mathrm{Pt}-\mathrm{Pd} / \mathrm{C}$ catalyst in alkaline media allowing building up reaction intermediates or products over the catalyst surface. Figure 11 shows current-time response on $\mathrm{Pt}-\mathrm{Pd} / \mathrm{C}$ at $-160 \mathrm{mV}$ for methanol oxidation in $0.5 \mathrm{M} \mathrm{NaOH}$ at different concentration of methanol for 1000 seconds. For all concentrations, the methanol oxidation current gradually decay with time due to the formation of subsequent intermediate species such as $\left(\mathrm{CH}_{3} \mathrm{OH}\right)_{\mathrm{ad}}, \mathrm{CHO}_{\mathrm{ad}}$, and $\mathrm{CO}_{\mathrm{ad}}$ during the methanol oxidation. Long-term poisoning rate $(\delta)$ can be calculated by measuring the linear decay of the current at times greater than 500 seconds from Figure 11 [14]

$$
\delta=\frac{100}{i_{0}} \times\left(\frac{d i}{d t}\right)_{t>500 \mathrm{sec}}(\% \text { per sec }),
$$

where $(d i / d t)_{t>500 \mathrm{sec}}$ is the slope of the linear portion of the current decay and $i_{0}$ is the current at the start of polarization back extrapolated from the linear current decay. The calculated $\delta$ values are given in the Table 1 . It is evident from the Table that the long-term poisoning rates increase with the increase in concentration of methanol although the initial methanol oxidation current is relatively high for higher methanol concentration. A steady value of current was observed up to $0.5 \mathrm{M}$ methanol, and at higher concentration of methanol, the value of current decreases even after 1000 seconds of measurement. With the accumulation of adsorbed intermediate species at higher concentration methanol, the current decreases with time. At this stage, some amount of $\mathrm{CO}_{2}$ production is expected, which may increase the carbonate concentration in the anolyte resulting in the concentration polarization [4]. At lower concentration of methanol, the formation of $\mathrm{CO}_{2}$ as well as adsorbed intermediates is negligible resulting in steady current over a long period of time. The overall methanol oxidation current on $\mathrm{Pt}-\mathrm{Pd} / \mathrm{C}$ electrode is maintained at higher level up to methanol concentration $2.0 \mathrm{M}$. beyond this concentration at 3.0 M methanol; there is a clear tradeoff for the oxidation current due to the combined effect of electrode poisoning and concentration polarization. The results are in agreement with the result of the cyclic voltammetry. In all cases, initial decay in methanol oxidation current is related to the formation of metal oxide [59]. The rate of current decay is very low at longer times, indicating the prevailing pseudosteady state kinetic conditions [60]. In chronoamperometric experiments, the current does not reach a stationary behavior even after several hours. Electrode deactivation is caused mainly due to the oxidation of metal surface. The other factor causing the decay of current is apparently the blockage of surface by some organic residue, which is slowly formed and can only be oxidized at high anodic potentials to the ultimate product [61].

3.6.2. Effect of $\mathrm{NaOH}$ Concentration. The stability of methanol oxidation on $\mathrm{Pt}-\mathrm{Pd} / \mathrm{C}$ electrode at a fixed concentration of $1.0 \mathrm{M}$ methanol with various concentration of $\mathrm{NaOH}$ was investigated by chronoamperometry at a potential of $-160 \mathrm{mV}$, as shown in Figure 12. An increase in methanol oxidation current was observed with the increase in $\mathrm{NaOH}$ concentration, and results are in agreement with the results

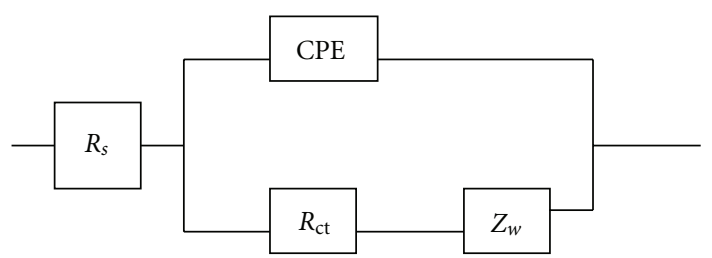

Figure 14: Proposed equivalent circuit for the methanol oxidation on Pt-Pd/C catalyst in a solution containing $0.5 \mathrm{M} \mathrm{NaOH}$ and $1.0 \mathrm{M}$ methanol at $140 \mathrm{mV}$. ( $R_{s}$ : solution resistance CPE: constant phase element $R_{\mathrm{ct}}$ : Charge transfer resistance, and $Z_{w}$ : warburg impedance).

of cyclic voltammetric experiments (Figure 8). The longterm poisoning rate $(\delta)$ for methanol oxidation with various concentration of $\mathrm{NaOH}$ was calculated by the Equation (38), and the values are given in the Table 1 . At low concentration of $\mathrm{NaOH}(0.1 \mathrm{M})$, the methanol oxidation current is comparatively less although the rate of poisoning is the least. This is due to the presence of fewer number of $\mathrm{OH}^{-}$ions at the electrode surface, compared to methanol molecules in large number. At the concentration of $\mathrm{NaOH}$ as high as 3.0 M, rapid decay of the oxidation current was observed (Figure 12) which is also evident from the high rate of poisoning (Table 1) of the electrode surface.

\subsection{Electrochemical Impedance Spectroscopic (EIS) Study}

3.7.1. Effect of Potential on the Impedance Response. EIS was used to investigate the overall kinetics of methanol oxidation at different potentials. The technique enabled to dissect the various impedance parameters for the charge transfer reaction occurring across the electrode solution interface. Nyquist plots for methanol oxidation for $1.0 \mathrm{M}$ methanol in $0.5 \mathrm{M} \mathrm{NaOH}$ solution at $25^{\circ} \mathrm{C}$ are shown in Figure 13 . The effective charge transfer resistance $\left(R_{\mathrm{ct}}\right)$ was used to analyze the electrode kinetics of the reaction process. In the low potential region $(E<-360 \mathrm{mV})$, shown in Figure 13(a), the Nyquist plot is characterized by a capacitive feature, as expected for hydrogen adsorption/desorption and double layer charging/discharging phenomena [57]. However, at moderate potential region that is, the Tafel region for the present case $(-360<E<-110 \mathrm{mV})$, there is a changeover from capacitive behavior to resistive behavior, as shown in Figure 13(b). At these potentials, the Nyquist plot resembles a semicircle, which can be assigned to kinetically controlled reaction. The small arc in the high frequency region may be associated with the chemisorption and dehydrogenation of the methanol molecule at the initial stage of the oxidation process. A charge transfer resistance $\left(R_{\mathrm{ct}}\right)$ for the kinetically controlled reactions may be represented by the diameter of the semicircle in the medium frequency and is related to the charge transfer reaction kinetics according to

$$
\begin{gathered}
R_{\mathrm{ct}}=\frac{\mathrm{RT}}{\mathrm{nFi}_{0}}, \\
i_{o}=n F A k_{o} C_{o}^{(1-\alpha)} C_{R}^{\alpha},
\end{gathered}
$$


TABLE 1: Variation of long-term poisoning rate $(\delta)$, charge transfer resistance $\left(R_{\mathrm{ct}}\right)$, and solution resistance $\left(R_{s}\right)$ for methanol oxidation on $\mathrm{Pt}-\mathrm{Pd} / \mathrm{C}$ electrode at various methanol and $\mathrm{NaOH}$ concentrations at $-160 \mathrm{mV}$.

\begin{tabular}{lccccccccccc}
\hline & \multicolumn{4}{c}{ Methanol concentration $(\mathrm{M})$} & \multicolumn{4}{c}{ NaOH concentration (M) } \\
& 0.1 & 0.2 & 0.5 & 1.0 & 2.0 & 3.0 & 0.1 & 0.5 & 1.0 & 2.0 & 3.0 \\
\hline$\delta(\%$ per sec) & 0.006 & 0.008 & 0.013 & 0.027 & 0.031 & 0.034 & 0.009 & 0.024 & 0.021 & 0.035 & 0.040 \\
$R_{\mathrm{ct}}(\mathrm{ohm})$ & 9.59 & 7.23 & 6.10 & 4.17 & 4.05 & 3.96 & 19.00 & 4.17 & 2.94 & 2.14 & 2.10 \\
$R_{s}(\mathrm{ohm})$ & 4.30 & 4.35 & 4.40 & 4.47 & 4.50 & 4.52 & 19.15 & 4.47 & 2.72 & 1.88 & 1.02 \\
\hline
\end{tabular}

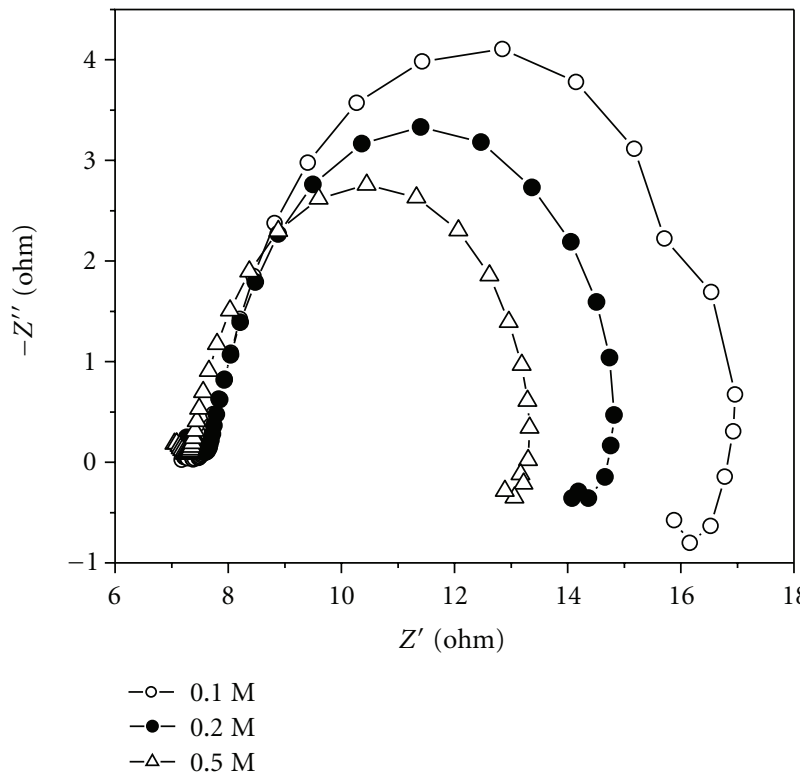

(a)

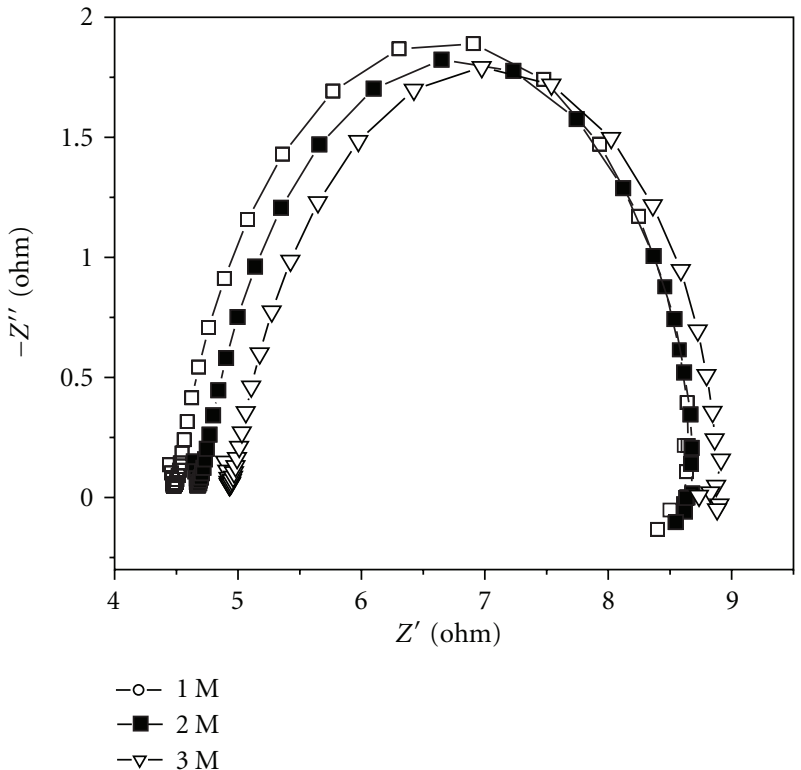

(b)

FIGURE 15: Impedance spectra (Nyquist plot) for methanol oxidation on Pt-Pd/C catalyst in $0.5 \mathrm{M} \mathrm{NaOH}$ with various concentrations of methanol at $-160 \mathrm{mV}$ and $25^{\circ} \mathrm{C}$.

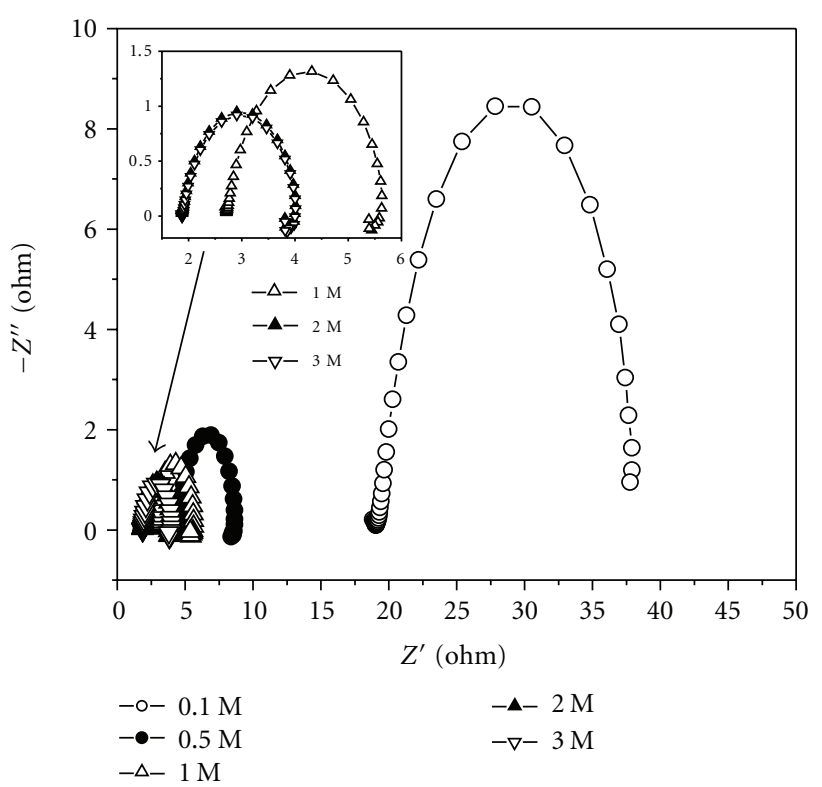

Figure 16: Impedance spectra (Nyquist plot) for methanol oxidation on Pt-Pd/C catalyst in $1.0 \mathrm{M}$ methanol with various concentrations of $\mathrm{NaOH}$ at $-160 \mathrm{mV}$ and $25^{\circ} \mathrm{C}$. where $R$ : molar gas constant $\left(\mathrm{J} \mathrm{mol}^{-1} \mathrm{k}^{-1}\right) ; T$ : temperature $(\mathrm{K})$; $n$ : number of electrons transferred; $F$ : Faraday constant (C); $i_{0}$ : exchange current $(\mathrm{A}) ; A$ : reaction area $\left(\mathrm{cm}^{2}\right)$; $k_{0}$ : standard heterogeneous rate constant $(\mathrm{cm} \mathrm{sec}-1) ; \mathrm{C}_{0}$, $\mathrm{C}_{R}$ : bulk concentration of oxidant and reductant species $\left(\mathrm{mol} \mathrm{L}^{-1}\right) ; \alpha$ : transfer coefficient. The charge transfer resistance is closely related to potential within the Tafel region. The values of charge transfer resistance at different potentials are given in the Table 2 , from where it is observed that $R_{\mathrm{ct}}$ decreases with increasing potential, indicating faster reaction kinetics at higher potentials. The depression in the arcs with potential may result from a high degree of heterogeneity at the electrode surface, and in such a case, the double-layer capacitance may be expressed taking into consideration the constant phase element (CPE) $[4,57]$.

Impedance can be written as

$$
Z_{\mathrm{CPE}}=\frac{1}{T(j \omega)^{\varnothing}},
$$

where $T$ is a constant in $F \mathrm{~cm}^{-2} \mathrm{~s}^{\emptyset-1} j=\sqrt{ }(-1) \omega$ is the angular frequency, and $\varnothing$ is related to the depression angle $\alpha$ according to $\alpha=(1-\varnothing) 90^{\circ}$. At potentials greater than $-160 \mathrm{mV}$, Figure 13 (c), a straight line appeared on the 
TABle 2: Charge transfer resistance $\left(R_{\mathrm{ct}}\right)$ for methanol oxidation on Pt-Pd/C electrode in a solution containing $0.5 \mathrm{M} \mathrm{NaOH}$ and $1.0 \mathrm{M}$ methanol at various potentials.

\begin{tabular}{cccccccccccc}
\hline & \multicolumn{1}{c}{ Potential $(\mathrm{mV})$} \\
& -460 & -410 & -360 & -310 & -260 & -210 & -160 & -60 & 40 & 100 & 140 \\
\hline$R_{\mathrm{ct}}(\mathrm{ohm})$ & 292.0 & 199.6 & 60.0 & 34.8 & 16.3 & 11.3 & 4.1 & 3.1 & 2.45 & 2.42 & 2.38 \\
\hline
\end{tabular}

TABLE 3: Calculated impedance parameters from the equivalent circuit for the methanol oxidation on $\mathrm{Pt}-\mathrm{Pd} / \mathrm{C}$ electrode in solution containing $0.5 \mathrm{M} \mathrm{NaOH}$ and $1.0 \mathrm{M}$ methanol at $140 \mathrm{mV}$.

\begin{tabular}{lccc}
\hline$R_{s}(\mathrm{ohm})$ & $\mathrm{CPE}(\mathrm{mF})$ & $R_{\mathrm{ct}}(\mathrm{ohm})$ & $Z_{w}(\mathrm{ohm})$ \\
\hline 4.75 & 1.58 & 2.38 & 0.80 \\
\hline
\end{tabular}

Nyquist plot at low frequencies. This can be attributed to the Warburg impedance $\left(Z_{w}\right)$ associated with a diffusion control process [57]. Potential independent nature of the charge transfer resistance beyond $-60 \mathrm{mV}$ (Table 2) also support the diffusion control nature of the reaction. In addition to the Warburg impedance, two arcs at higher frequencies are associated with the adsorption (high frequency) and kinetic (medium frequency) process. On the basis of the impedance behavior, an equivalent circuit is suggested in Figure 14. For curve fitting calculations, impedance spectra for methanol oxidation at $140 \mathrm{mV}$ (Figure 13(c)) was considered. The calculated impedance parameters are shown in Table 3. The low level of $\mathrm{OH}^{-}$perhaps generates unfavorable impedance parameters even at higher potential values.

3.7.2. Effect of Methanol Concentration on the Impedance Response for Methanol Oxidation. The effect of the methanol concentration on the impedance response in $0.5 \mathrm{M} \mathrm{NaOH}$ is shown by the Nyquist plots, recorded at $-160 \mathrm{mV}$ in Figure 15. It is observed from Table 1 that at lower concentration range of methanol, the charge transfer resistance decreased with increasing methanol concentration. This behavior suggests that the reaction kinetics were enhanced by the adsorption of methanol on the electrode surface. However, too high concentrations of methanol do not favor the reaction kinetics, and the catalyst may be subject to poisoning effect in this potential and concentration range. The high values of charge transfer resistance for all concentration of methanol suggest slow reaction kinetics. These results are in agreement with those obtained from voltammetric studies. For low methanol concentration and at this potential, a feeble inductive feature was observed at low-frequency region, indicating the possibility of oxidation of organic residues including CO present at the electrode surface [28].

3.7.3. Effect of $\mathrm{NaOH}$ Concentration on the Impedance Response for Methanol Oxidation. Figure 16 shows Nyquist plots for methanol oxidation at $-160 \mathrm{mV}$ for a set of $\mathrm{NaOH}$ concentrations. The values of the charge transfer resistance $\left(R_{\mathrm{ct}}\right)$ and solution resistance $\left(R_{s}\right)$ are given in the Table 1. From Figure 16 and Table 1, it is clear that the charge transfer resistance and solution resistance decreased with increase of $\mathrm{NaOH}$ concentration. This indicates that the reaction becomes facile with increasing $\mathrm{OH}^{-}$concentration, which also supports the voltammetric results.

\section{Conclusion}

The electrochemically synthesized Pt-Pd/C catalyst shows remarkably high activity towards methanol oxidation in alkaline media both in terms of oxidation peak current density and the onset potential. The peak current density of methanol oxidation on $\mathrm{Pt}-\mathrm{Pd} / \mathrm{C}$ catalyst increases with increasing the methanol concentration. For methanol concentration higher than $1.0 \mathrm{M}$, no appreciable change in the oxidation peak current density was observed. The results indicate that the reaction of the electro-oxidation of methanol is activation controlled process. A linear increase in methanol oxidation current density was observed with the increase in $\mathrm{NaOH}$ concentrations, suggesting better electrode kinetics at higher concentration of $\mathrm{NaOH}$. The optimum methanol/ $\mathrm{OH}^{-}$concentration ratio is $1: 2$. The kinetics of the methanol oxidation reaction on the $\mathrm{Pt}-\mathrm{Pd} / \mathrm{C}$ electrode was determined by the surface coverage of $\mathrm{OH}^{-}$species on the electrode surface. A reaction order of 0.45 and 0.70 were obtained for methanol and $\mathrm{NaOH}$, respectively.

The Pt-Pd/C catalyst showed good stability over a moderately extended period of time. The low value of Tafel slope and charge transfer resistance also suggests that the electrode could be promising for application in DMFCs in alkaline medium.

\section{Acknowledgment}

The authors gratefully acknowledge the financial support of the Defense Research and Development Organization (DRDO), New Delhi, India.

\section{References}

[1] W. Qian, D. P. Wilkinson, J. Shen, H. Wang, and J. Zhang, "Architecture for portable direct liquid fuel cells," Journal of Power Sources, vol. 154, no. 1, pp. 202-213, 2006.

[2] H. Fukunaga, T. Ishida, N. Teranishi, C. Arai, and K. Yamada, "Impedance of vapor feed direct methanol fuel cells-polarization dependence of elementary processes at the anode," Electrochimica Acta, vol. 9, no. 13, pp. 2123-2129, 2004.

[3] H. Liu and J. Zhang, Electrocatalysis of Direct Methanol Fuel Cells, Wiley, Weinheim, Germany, 2009.

[4] E. H. Yu, K. Scott, and R. W. Reeve, "A study of the anodic oxidation of methanol on Pt in alkaline solutions," Journal of Electroanalytical Chemistry, vol. 547, no. 1, pp. 17-24, 2003.

[5] Y. X. Chen, A. Miki, S. Ye, H. Sakai, and M. Osawa, "Formate, an active intermediate for direct oxidation of methanol on $\mathrm{Pt}$ electrode," Journal of the American Chemical Society, vol. 125, no. 13, pp. 3680-3681, 2003. 
[6] R. Parsons and T. VanderNoot, "The oxidation of small organic molecules. A survey of recent fuel cell related research," Journal of Electroanalytical Chemistry, vol. 257, no. 1-2, pp. 9 45, 1988.

[7] W. H. Lizcano-Valbuena, V. A. Paganin, and E. R. Gonzalez, "Methanol electro-oxidation on gas diffusion electrodes prepared with Pt-Ru/C catalysts," Electrochimica Acta, vol. 47, no. 22-23, pp. 3715-3722, 2002.

[8] W. Li, W. Zhou, H. Li et al., "Nano-stuctured Pt-Fe/C as cathode catalyst in direct methanol fuel cell," Electrochimica Acta, vol. 49, no. 7, pp. 1045-1055, 2004.

[9] A. B. Anderson, E. Grantscharova, and S. Seong, "Systematic theoretical study of alloys of platinum for enhanced methanol fuel cell performance," Journal of the Electrochemical Society, vol. 143, no. 6, pp. 2075-2082, 1996.

[10] E. Reddington, A. Sapienza, B. Gurau et al., "Combinatorial electrochemistry: a highly parallel, optical screening method for discovery of better electrocatalysts," Science, vol. 280, no. 5370, pp. 1735-1737, 1998.

[11] A. L. Ocampo, M. Miranda-Hernandez, J. Morgado, J. A. Montoya, and P. J. Sebastian, "Characterization and evaluation of Pt-Ru catalyst supported on multi-walled carbon nanotubes by electrochemical impedance," Journal of Power Sources, vol. 160, no. 2, pp. 915-924, 2006.

[12] C. Bock, M. A. Blakely, and B. MacDougall, "Characteristics of adsorbed $\mathrm{CO}$ and $\mathrm{CH}_{3} \mathrm{OH}$ oxidation reactions for complex Pt/Ru catalyst systems," Electrochimica Acta, vol. 50, no. 12, pp. 2401-2414, 2005.

[13] T. T. Cheng and E. L. Gyenge, "Electrodeposition of mesoscopic Pt-Ru on reticulated vitreous carbon from reverse emulsions and microemulsions: application to methanol electro-oxidation," Electrochimica Acta, vol. 51, no. 19, pp. 39043913, 2006.

[14] J. W. Guo, T. S. Zhao, J. Prabhuram, R. Chen, and C. W. Wong, "Development of PtRu-CeO2/C anode electrocatalyst for direct methanol fuel cells," Journal of Power Sources, vol. 156, no. 2, pp. 345-354, 2006.

[15] G. Samjeske, H. Wang, T. Loffler, and H. Baltruschat, "CO and methanol oxidation at Pt-electrodes modified by Mo," Electrochimica Acta, vol. 47, no. 22-23, pp. 3681-3692, 2002.

[16] B. Rajesh, K. R. Thampi, J. M. Bonard et al., "Pt particles supported on conducting polymeric nanocones as electro-catalysts for methanol oxidation," Journal of Power Sources, vol. 133, no. 2, pp. 155-161, 2004.

[17] T. J. Schmidt, P. N. Ross, and N. M. Markovic, "Temperaturedependent surface electrochemistry on Pt single crystals in alkaline electrolyte: part 1: CO oxidation," Journal of Physical Chemistry B, vol. 105, no. 48, pp. 12082-12086, 2001.

[18] M. C. Preez, A. Rincon, and C. Gutierrez, "Effect of chloride ions on the electrooxidation at low potentials of dissolved carbon monoxide on platinum," Journal of Electroanalytical Chemistry, vol. 511, no. 1-2, pp. 39-45, 2001.

[19] E. Santos and M. C. Giordano, "Electrooxidation of adsorbed CO on polycrystalline platinum in alkaline solutions," Journal of Electroanalytical Chemistry, vol. 172, no. 1-2, pp. 201-210, 1984.

[20] S. Shi-Gang and C. Ai, "In situ FTIRS features during oxygen adsorption and carbon monoxide oxidation at a platinum electrode in dilute alkaline solutions," Journal of Electroanalytical Chemistry, vol. 323, no. 1-2, pp. 319-328, 1992.

[21] M. Hachkar, T. Napporn, J. M. Léger, B. Beden, and C. Lamy, "An electrochemical quartz crystal microbalance investigation of the adsorption and oxidation of $\mathrm{CO}$ on a platinum electrode," Electrochimica Acta, vol. 41, no. 17, pp. 2721-2730, 1996.
[22] J. Prabhuram and R. Manoharan, "Investigation of methanol oxidation on unsupported platinum electrodes in strong alkali and strong acid," Journal of Power Sources, vol. 74, no. 1, pp. 54-61, 1998.

[23] A. Verma and S. Basu, "Direct alkaline fuel cell for multiple liquid fuels: anode electrode studies," Journal of Power Sources, vol. 174, no. 1, pp. 180-185, 2007.

[24] M. Schulze and E. Gulzow, "Degradation of nickel anodes in alkaline fuel cells," Journal of Power Sources, vol. 127, no. 1-2, pp. 252-263, 2004.

[25] M. A. Abdel Rahim, R. M. Abdel Hameed, and M. W. Khalil, "Nickel as a catalyst for the electro-oxidation of methanol in alkaline medium," Journal of Power Sources, vol. 134, no. 2, pp. 160-169, 2004.

[26] L. K. Verma, "Studies on methanol fuel cell," Journal of Power Sources, vol. 86, no. 1, pp. 464-468, 2000.

[27] R. Manoharan and J. Prabhuram, "Possibilities of prevention of formation of poisoning species on direct methanol fuel cell anodes," Journal of Power Sources, vol. 96, no. 1, pp. 220-225, 2001.

[28] J. T. Muller, P. M. Urban, and W. F. Holderich, "Impedance studies on direct methanol fuel cell anodes," Journal of Power Sources, vol. 84, no. 2, pp. 157-160, 1999.

[29] C. Lamy, A. Lima, V. LeRhun, F. Delime, C. Coutanceau, and J. M. Léger, "Recent advances in the development of direct alcohol fuel cells (DAFC)," Journal of Power Sources, vol. 105, no. 2, pp. 283-296, 2002.

[30] K. Matsuoka, Y. Iriyama, T. Abe, M. Matsuoka, and Z. Ogumi, "Electro-oxidation of methanol and ethylene glycol on platinum in alkaline solution: poisoning effects and product analysis," Electrochimica Acta, vol. 51, no. 6, pp. 1085-1090, 2005.

[31] E. Gülzow and M. Schulze, "Long-term operation of AFC electrodes with $\mathrm{CO}_{2}$ containing gases," Journal of Power Sources, vol. 127, no. 1-2, pp. 243-251, 2004.

[32] E. Agel, J. Bouet, and J. F. Fauvarque, "Characterization and use of anionic membranes for alkaline fuel cells," Journal of Power Sources, vol. 101, no. 2, pp. 267-274, 2001.

[33] J. R. Varcoe, R. C. T. Slade, E. L. W. Yee, S. D. Poynton, and D. J. Driscoll, "Investigations into the ex situ methanol, ethanol and ethylene glycol permeabilities of alkaline polymer electrolyte membranes," Journal of Power Sources, vol. 173, no. 1, pp. 194199, 2007.

[34] J. S. Spendelow, G. Q. Lu, P. J. A. Kenis, and A. Wieckowski, "Electrooxidation of adsorbed $\mathrm{CO}$ on $\mathrm{Pt}(111)$ and $\mathrm{Pt}(111) / \mathrm{Ru}$ in alkaline media and comparison with results from acidic media," Journal of Electroanalytical Chemistry, vol. 568, no. 12, pp. 215-224, 2004.

[35] S. Grigoriev, E. Lyutikova, S. Martemianov, V. Fateev, C. Lebouin, and P. Millet, "Palladium-based electrocatalysts for PEM applications," in Proceedings of the 16th World hydrogen Energy Conference (WHEC 2006), Lyon, France, 2006.

[36] A. Y. Tsivadze, M. R. Tarasevich, V. N. Andreev, and V. A. Bogdanovskaya, "Prospects of low-temperature platinum-free fuel cells," Russian Journal of General Chemistry, vol. 77, no. 4, pp. 783-789, 2007.

[37] J. Prabhuram, R. Manoharan, and H. N. Vasan, "Effects of incorporation of $\mathrm{Cu}$ and $\mathrm{Ag}$ in $\mathrm{Pd}$ on electrochemical oxidation of methanol in alkaline solution," Journal of Applied Electrochemistry, vol. 28, no. 9, pp. 935-941, 1998.

[38] B. Veisz, L. Toth, D. Teschner et al., "Palladium-platinum powder catalysts manufactured by colloid synthesis," Journal of Molecular Catalysis A, vol. 238, no. 1-2, pp. 56-62, 2005. 
[39] O. Yepez and B. R. Scharifker, "Oxidation of CO on hydrogenloaded palladium," Journal of Applied Electrochemistry, vol. 29, no. 10, pp. 1185-1190, 1999.

[40] L. D. Burke and J. K. Casey, "The electrocatalytic behaviour of palladium in acid and base," Journal of Applied Electrochemistry, vol. 23, no. 6, pp. 573-582, 1993.

[41] G. Gokagac, J. M. Leger, and F. Hann, "Behaviour of bimetallic Pt-Pd carbon-supported catalysts in methanol electrooxidation," Zeitschrift für Naturforschung, vol. 58b, no. 5, pp. 423432, 2003.

[42] A. I. Vogel, A. R. Tatchell, B. S. Furnis, A. J. Hannaford, and P. W. G. Smith, Vogel's Text Book of Practical Organic Chemistry, Addison Wesley Longman, London, UK, 5th edition, 1998.

[43] Y. H. Qin, H. H. Yang, X. S. Zhang et al., "Electrophoretic deposition of network-like carbon nanofibers as a palladium catalyst support for ethanol oxidation in alkaline media," Carbon, vol. 48, no. 12, pp. 3323-3329, 2010.

[44] Z. X. Liang, T. S. Zhao, J. B. Xu, and L. D. Zhu, "Mechanism study of the ethanol oxidation reaction on palladium in alkaline media," Electrochimica Acta, vol. 54, no. 8, pp. 2203-2208, 2009.

[45] W. Jin, H. Du, S. Zheng, H. Xu, and Y. Zhang, "Comparison of the oxygen reduction reaction between $\mathrm{NaOH}$ and $\mathrm{KOH}$ solutions on a Pt electrode: the electrolyte-dependent effect," Journal of Physical Chemistry B, vol. 114, no. 19, pp. 6542$6548,2010$.

[46] C. Xu, L. Cheng, P. Shen, and Y. Liu, "Methanol and ethanol electrooxidation on Pt and Pd supported on carbon microspheres in alkaline media," Electrochemistry Communications, vol. 9, no. 5, pp. 997-1001, 2007.

[47] R. N. Singh, A. Singh, and Anindita, "Electrocatalytic activity of binary and ternary composite films of Pd, MWCNT and Ni, Part II: Methanol electrooxidation in $1 \mathrm{M} \mathrm{KOH,"} \mathrm{International}$ Journal of Hydrogen Energy, vol. 34, no. 4, pp. 2052-2057, 2009.

[48] S. Trasatti and O. A. Petrii, "Real surface area measurements in electrochemistry," Pure \& Applied Chemistry, vol. 63, no. 5, pp. 711-734, 1991.

[49] Q. Yi, W. Huang, X. Liu, G. Xu, Z. Zhou, and A. Chen, "Electroactivity of titanium-supported nanoporous Pd-Pt catalysts towards formic acid oxidation," Journal of Electroanalytical Chemistry, vol. 619-620, no. 1-2, pp. 197-205, 2008.

[50] L. H. Macao, M. C. Santos, S. A. S. Machado, and L. A. Avaca, "Underpotential deposition of silver on polycrystalline platinum studied by cyclic voltammetry and rotating ring-disc techniques," Journal of the Chemical Society-Faraday Transactions, vol. 93, no. 22, pp. 3999-4003, 1997.

[51] D. C. Papageorgopoulos, M. Keijzer, J. B. J. Veldhuis, and F. A. De Bruijn, "CO tolerance of Pd-Rich platinum palladium," Journal of the Electrochemical Society, vol. 149, no. 11, pp. A1400-A1404, 2002.

[52] C. Nishihara and T. Okada, "Note on the oxidation of methanol at Pt (111) and Pt (332) electrodes in alkaline solutions," Journal of Electroanalytical Chemistry, vol. 577, no. 2, pp. 355-359, 2005.

[53] M. C. Morin, C. Lamy, J. M. Leger, J. L. Vasquez, and A. Aldaz, "Structural effects in electrocatalysis: oxidation of ethanol on platinum single crystal electrodes. Effect of pH," Journal of Electroanalytical Chemistry, vol. 283, no. 1-2, pp. 287-302, 1990.

[54] C. Xu, Y. Liu, and D. Yuan, "Pt and Pd supported on carbon microspheres for alcohol electrooxidation in alkaline media," International Journal of Electrochemical Science, vol. 2, no. 9, pp. 674-680, 2007.
[55] M. H. Pournaghi-Azar and B. Habibi-A, "Preparation of a platinum layer-modified aluminum electrode by electrochemical and electroless cementations and its use for the electrooxidation of methanol," Journal of Electroanalytical Chemistry, vol. 580, no. 1, pp. 23-34, 2005.

[56] A. V. Tripkovic and K. D. Popovic, "Oxidation of methanol on platinum single crystal stepped electrodes from [110] zone in acid solution," Electrochimica Acta, vol. 41, no. 15, pp. 23852394, 1996.

[57] E. H. Yu, K. Scott, R. W. Reeve, L. Yang, and R. G. Allen, "Characterisation of platinised Ti mesh electrodes using electrochemical methods: methanol oxidation in sodium hydroxide solutions," Electrochimica Acta, vol. 49, no. 15, pp. 24432452, 2004.

[58] A. V. Tripkovic, K. Dj. Popovic, J. D. Lovic, V. M. Jananovic, and A. Kowal, "Methanol oxidation at platinum electrodes in alkaline solution: comparison between supported catalysts and model systems," Journal of Electroanalytical Chemistry, vol. 572, no. 1, pp. 119-128, 2004.

[59] G. Yu, L. Li, and B.-Q. Xu, "Effect of electrochemical polarization of $\mathrm{PtRu} / \mathrm{C}$ catalysts on methanol electrooxidation," Electrochimica Acta, vol. 50, no. 1, pp. 1-10, 2004.

[60] G. T. Filho, H. Kim, W. Chrzanowski, A. Wieckowski, B. Grzybowska, and P. Kulesza, "Reactivity and activation parameters in methanol oxidation on platinum single crystal electrodes "decorated" by ruthenium adlayers," Journal of Electroanalytical Chemistry, vol. 467, no. 1, pp. 143-156, 1999.

[61] W. Vielstich, H. Gasteiger, and A. Lamm, Handbook of Fuel Cells: Fundamentals, Technology and Applications, vol. 4, John Wiley \& Sons, Chichester, UK, 2003. 


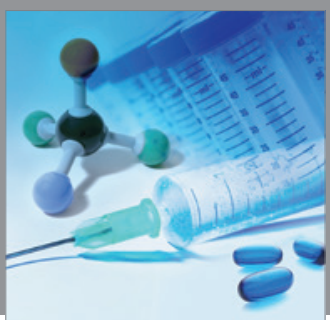

International Journal of

Medicinal Chemistry

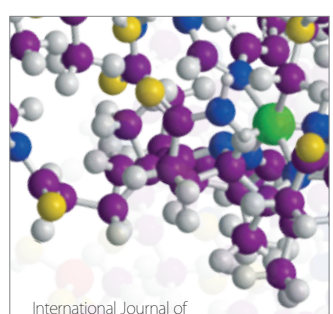

Carbohydrate Chemistry

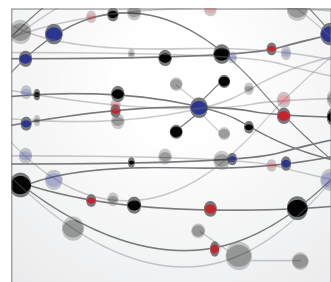

The Scientific World Journal
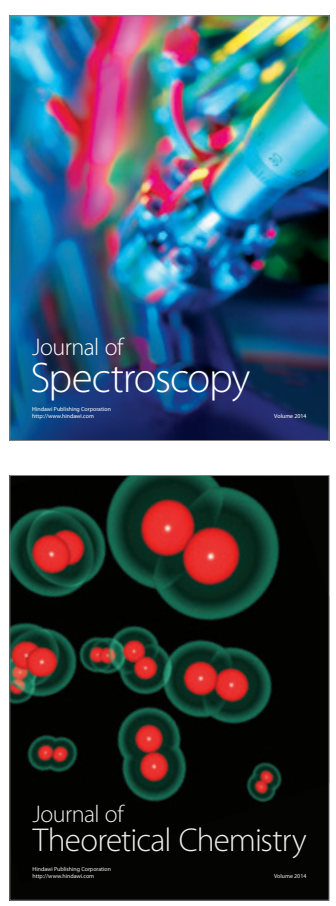
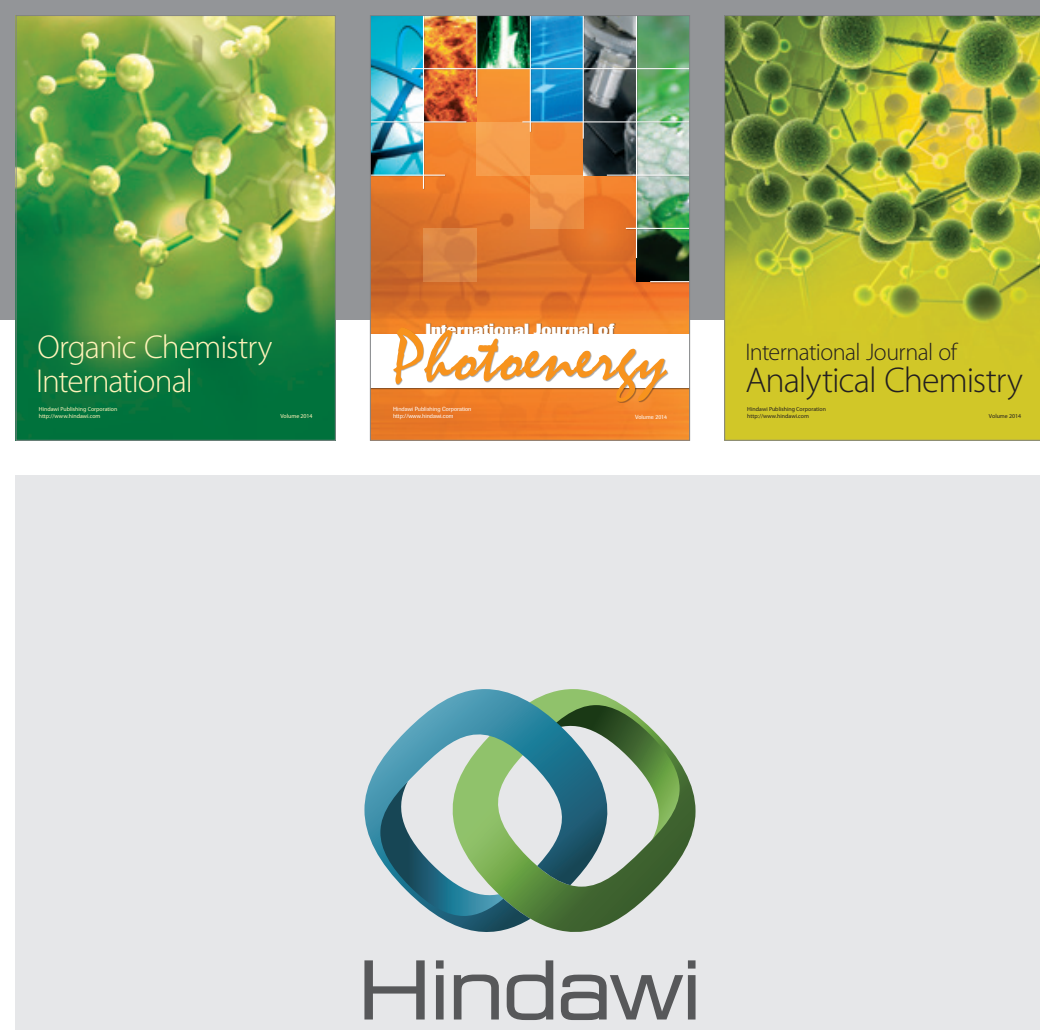

Submit your manuscripts at

http://www.hindawi.com
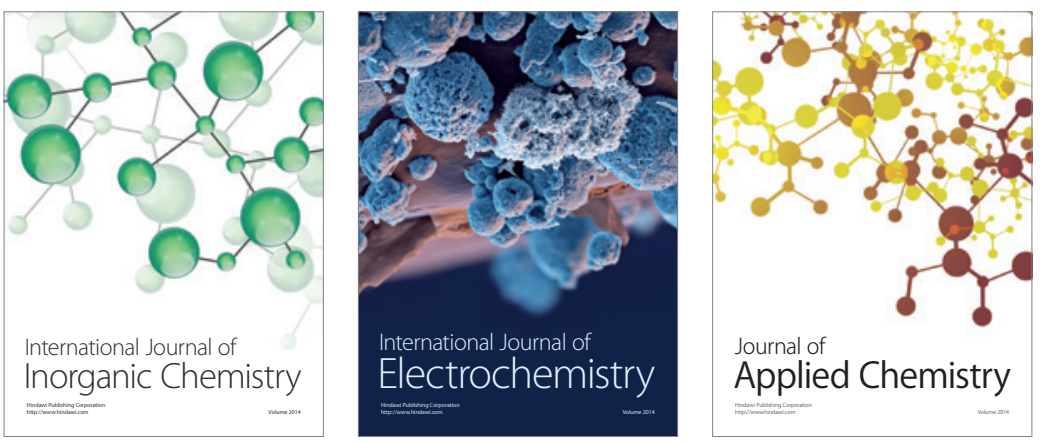

Journal of

Applied Chemistry
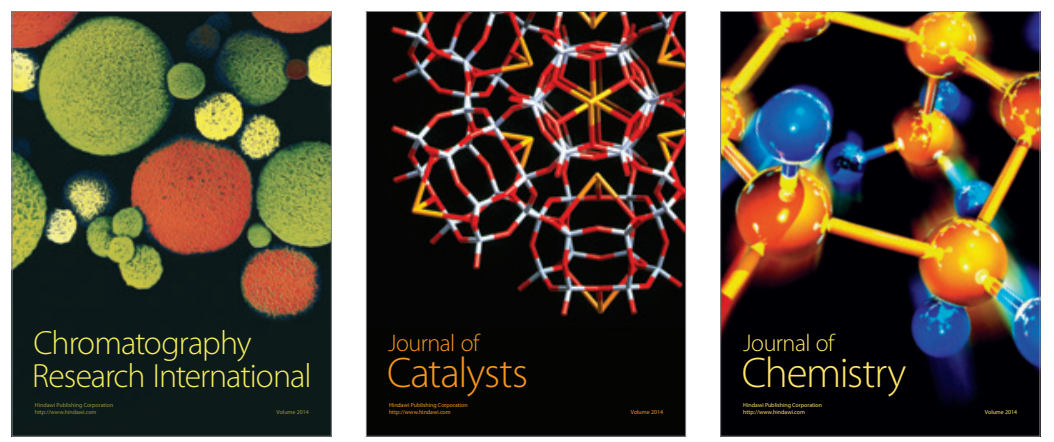
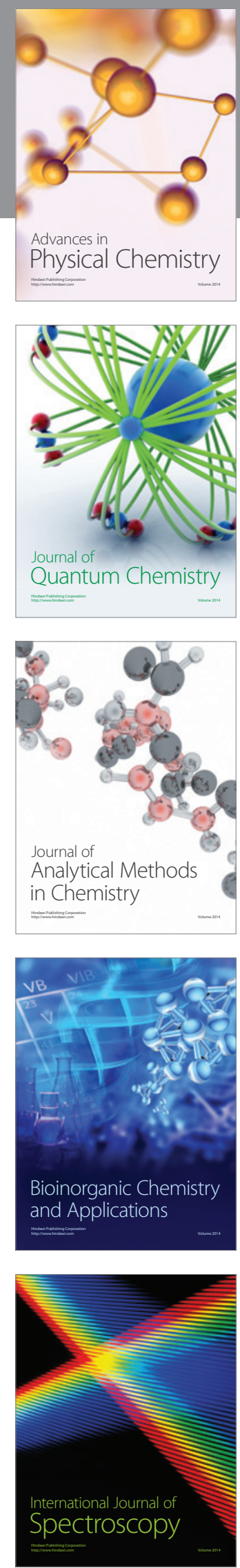